University of Pennsylvania Carey Law School

Penn Law: Legal Scholarship Repository

Faculty Scholarship at Penn Law

1989

\title{
Mark Tushnet on Liberal Constitutional Theory: Mission Impossible
}

Frank Goodman

University of Pennsylvania Carey Law School

Follow this and additional works at: https://scholarship.law.upenn.edu/faculty_scholarship

Part of the Constitutional Law Commons, Ethics and Political Philosophy Commons, First Amendment Commons, Fourteenth Amendment Commons, Jurisprudence Commons, Law and Philosophy Commons, Legal History Commons, Legal Theory Commons, and the Public Law and Legal Theory Commons

\section{Repository Citation}

Goodman, Frank, "Mark Tushnet on Liberal Constitutional Theory: Mission Impossible" (1989). Faculty Scholarship at Penn Law. 1406.

https://scholarship.law.upenn.edu/faculty_scholarship/1406

This Article is brought to you for free and open access by Penn Law: Legal Scholarship Repository. It has been accepted for inclusion in Faculty Scholarship at Penn Law by an authorized administrator of Penn Law: Legal Scholarship Repository. For more information, please contact PennlawIR@law.upenn.edu. 


\title{
ESSAY/BOOK REVIEW
}

\section{MARK TUSHNET \\ ON LIBERAL CONSTITUTIONAL THEORY: MISSION IMPOSSIBLE}

\author{
FRANK GOODMANं
}

If men were angels, no government would be necessary. If angels were to govern men, neither external nor internal controls on government would be necessary.

- James Madison ${ }^{1}$

But because men are neither angels nor governed by angels, external and internal controls on government are necessary but, alas, impossible.

- Mark V. Tushnet (liberally, you should pardon the expression, paraphrased) ${ }^{2}$

Liberalism assigns judicial review an impossible mission: to prevent the tyranny of the majority without creating a tyranny of the judges. What makes this mission necessary is precisely what makes it impossible: the self-aggrandizing individualism that liberalism takes to be the dominant tendency of human nature and that legislators and judges share with everyone else. Only in a society where civic virtue displaces self-interest as the wellspring of political action would benign judicial oversight be possible, though by the same token unnecessary. This, in brief, is the thesis of Red, White, and Blue, Mark Tushnet's wide-ranging and incisive critique of contemporary constitutional

† Professor of Law, University of Pennsylvania. I wish to thank my colleagues Howard Lesnick, Steve Morse, and Mike Schill for their helpful suggestions and advice. Special thanks are due Steve Burbank for his exceptional generosity in reading and commenting on more than one draft and Seth Kreimer for his extensive and insightful criticisms of the paper at a faculty seminar at Penn. Finally, I am greatly indebted to David Colton, without whose patience, wise counsel, and tireless assistance this project might never have left the ground and certainly would not have landed.

1 The Federalist No. 51 (J. Madison) (C. Rossiter ed. 1961).

$2 \mathrm{M}$. Tushnet, Red, White, and Blue: A Critical Analysis of ConstituTIONAL LAW (1988). 
theory.

The last decade has witnessed a remarkable proliferation of theoretical writing about the Constitution, its interpretation, and its role in our political culture. Today's legal landscape fairly blooms with constitutional theories. This terrain is comprehensively mapped and brilliantly illuminated in Red, White, and Blue. I know of no other volume that provides so complete a picture or so penetrating a dissection of the work of contemporary constitutional scholars. Although a large portion of the book has appeared in law review articles spanning nearly a decade, the work as a whole states and develops a coherent thesis. Tushnet himself apparently regards his enterprise as exclusively critical and disclaims any intent to put forward a theory of his own. But his systematic analysis of the failure of other people's theories amounts, in effect, to a "metatheory" in its own right. It is this metatheory that I propose to evaluate in the essay that follows. I find it wanting in many respects, but this does not detract from my admiration for the work as a whole.

Tushnet begins by noting the recent revival of interest in comprehensive normative theories-"grand theories," he calls them-that attempt to provide justifications for the power of judges with lifetime appointments "to displace decisions made by representatives of the people." Three such grand theories have occupied center stage in the contemporary debate: originalism, ${ }^{4}$ representation-reinforcement, ${ }^{5}$ and non-originalism. ${ }^{6}$ The three chapters forming the core of Red, White, and $B l u e^{7}$ contain powerful critiques of each of these grand theories.

3 Id. at 1.

- Originalism holds that in a democracy judges should not overturn the decisions of legislators except as authorized by "the words of the Constitution as understood by the framers." Id. at 23 . Originalists may differ as to the flexibility with which these words should be read, in the absence of clear intent, but they agree that courts should not base countermajoritarian decisions on values or principles not contained in the document.

- Representation-reinforcing theories of review would further justify judicial intervention in the name of democracy itself, that is "either to eliminate the failures of the political market so that it would work properly in the future or, more controversially, to mimic the results that would have occurred had the political market been operating properly." Id. at 71 . Interventions of the first type include the reapportionment and voting rights decisions; those of the second type include race discrimination and other decisions protective of groups deemed unable to participate effectively in the political process.

${ }^{8}$ Non-originalist theories would additionally authorize countermajoritarian action on the basis of norms drawn from moral philosophy and other sources external to the written document, for instance, by protecting under the fourteenth amendment textually unspecified rights deemed by the Court to be "fundamental." Roe v. Wade, 410 U.S. 113 (1973), of course, is the paradigm.

"In addition to its core analysis of the "grand theories," Red, White, and Blue also discusses a multitude of other approaches to constitutional law: intuitionist, or bal- 
Each theory is measured by its success or failure in providing the constraints required by the liberal tradition to eliminate the risk of tyranny-by both legislators and judges.

For Tushnet, the liberal tradition, along with its close relative, the civic republican tradition, were "general theories about citizenship" that competed on roughly equal terms during the era in which the Constitution was framed..$^{8}$ Liberalism emphasized "the basic individualism of people acting in society"; following Thomas Hobbes, it considered people to be motivated primarily by what C.B. MacPherson has called "possessive individualism," the desire to maximize their material well-being. ${ }^{10}$ Those who exercised government power, therefore, could be expected to abuse it for their own advantage unless firmly constrained by institutional checks. Judicial review was one such check, but by itself it was "an unstable solution to liberalism's problems, because the framers, as liberals, had no reason to think that judges would be any less attached to possessive individualism than were the representatives whom the judges were to restrain."11 Judicial review "thus substituted the threat of tyranny by the judges for the threat of tyranny by the legislators. Modern constitutional theory attempts to provide the

ancing, theories, see M. TUSHNET, supra note 2, at 158-60, 183-84; "neutral principles," see id. at 46-57; "territorial strategies" assigning specific areas of adjudication to different grand theories, see id. at 181-82; "antiformalist" theories (so-called because they reject liberalism's supposed desire for formal constraints), both "anarchist" (treating constitutional decisions as dialogue or rhetoric rather than coercion), see id. at 14959 , and "republican" (calling for a politics and a jurisprudence of "public values"), see $i d$. at 160-68; structural review, see id. at 201-13; Burkean approaches, see id. at 17778 ; and so on and on.

The remainder of the book is a series of chapters devoted to discrete areas of constitutional law. One discusses the welfare bureaucracy, arguing that the Supreme Court's deference to professional norms in the formulation of constitutional rules reflects an image of the bureaucracy as an institution characterized by rationality and professional competence, a far cry from reality as Tushnet sees it. See id. at 214-46. Another chapter surveys the current doctrinal disarray in the interpretation of the religion clauses of the first amendment. See id. at 247-76. Tushnet attributes this confusion to the inability of the liberal tradition, which dominates our constitutional jurisprudence, to understand or take seriously an institution, intermediate between the individual and the state, having strong communal character. The final chapter deals with the constitutional law of campaign financing, commercial speech, and pornography-activities that contribute importantly to the shaping of preferences in the United States. See id. at 277-312. Each chapter bristles with insights that amply repay the reader's close attention.

Id. at 4.

๑ C.B. Macpherson, The Theory of Possessive Individualism: Hobbes to Locke (1962).

10 See M. Tushnet, supra note 2 , at 8 .

11 Id. at 10. 
necessary limits on judges." ${ }^{.12}$ Another passage expresses the same idea:

Judicial review is one of several mechanisms that the framers designed to enforce constitutional limits. Yet ... judicial review alone cannot eliminate the possibility of a certain kind of governmental oppression - oppression by the judges themselves. Constitutional theory completes the structure by providing guidance to the judges on when and how they should exercise the power of judicial review and by giving the citizenry widely shared criteria by which to evaluate judicial performance. ${ }^{13}$

It turns out, however, that no modern approach to constitutional law can supply the necessary restraints on both legislative and judicial tyranny. Originalism fails because its most coherent version "protects us against only those few specific forms of legislative tyranny that the framers had in mind"14 and because limited evidence, social change, and the inherent ambiguity of past beliefs and intentions deprive even seemingly cut-and-dried constitutional language of its capacity to bind judges. ${ }^{15}$ Representation-reinforcement fails on one of two grounds: either it confines the (non-originalist) role of the courts to the elimination (or counteraction) of purely formal obstacles to representation, in which case it does not adequately restrain legislators; or it authorizes courts to take account also of political realities that create informal obstacles to representation, in which case it leaves the judges themselves largely unconstrained..$^{16}$ Nonoriginalism fails because the principles of moral philosophy are either too abstract or too controversial to provide determinate answers to the concrete moral issues judges face and because judges are no better qualified (and in some ways are less well qualified) than legislators to provide these answers. Moral philosophy, the source to which non-originalism looks for guidance in identifying "fundamental" rights, cannot therefore constrain judges in the way the liberal tradition requires.

Thus, what Tushnet calls "the basic argument of the book," is

12 Id.

13 Id. at 4. Yet another formulation of the same basic theme states: "Judicial review is often defended as the only way to escape the potential tyranny of the majority, but it simultaneously creates the potential for the tyranny of the judges. The greatest function of constitutional theory has been to specify how judicial review can exist without becoming judicial tyranny." Id. at 16-17.

14 Id. at 32.

15 See id. at 36-44.

${ }^{16}$ See id. at $72-73,75,82-83,93-107$. 
simply this:

The liberal tradition makes constitutional theory both necessary and impossible. It is necessary because it provides the restraints that the liberal tradition requires us to place on those in power, legislators and judges as well. It is impossible because no available approach to constitutional law can effectively restrain both legislators and judges: If we restrain the judges we leave legislators unconstrained; if we restrain the legislators we let the judges do what they want. ${ }^{17}$

Unhappily, therefore, "we are left with a. choice of dictatorships; sometimes the majority will be the dictator, and sometimes the judges will." 18

Briefly stated, the principal contentions of this essay are as follows: First, Tushnet's "impossibility theorem"- -stated in the last two sentences of his "basic argument"-is undeniably but trivially true, especially given Tushnet's extraordinarily inclusive notion of tyranny. Second, Tushnet's contention that the liberal tradition demands of judicial review and constitutional theory that they perform this impossible checking function is historically insupportable. Third, what makes it impossible for any set of institutions to preclude tyranny (as Tushnet defines it) is not that selfishness is the ruling motive in human behavior, the Hobbesian hypothesis that Tushnet considers fundamental to liberalism, but that human beings, in our society at least, disagree strongly with one another on many issues of great importance to them. This lack of consensus would not disappear even if self-interest were eradicated altogether from our politics.

Parts I and II below deal, respectively, with Tushnet's claims (1) that constitutional theory cannot prevent judges from tyrannizing and (2) that judicial review itself cannot prevent legislators from tyrannizing. The two arguments are closely parallel. Neither judicial review nor constitutional theory can reasonably be expected to provide reliable protection against tyranny of the sort that Tushnet thinks liberalism demands. Part I points out that constitutional theory is not an external but an internal constraint, dependent on the willingness of judges to be guided by it; that our political system, however, as Tushnet himself acknowledges, contains a number of other restraints, both internal and external, that mitigate the danger of countermajoritarian excess by the courts; and that, all in all, judicial tyranny is not a serious threat. The 
examples Tushnet gives of it-the abortion, busing, and school prayer decisions-all presented conflicting claims of fundamental right that would have brought charges of tyranny-judicial tyranny or judicial acquiescence in legislative tyranny-no matter how the cases were decided. To criticize judicial review/constitutional theory for its failure to prevent "tyranny" when "tyranny" (in Tushnet's sense of it) is the inevitable consequence of our society's lack of consensus on the issues in question is to bay at the moon.

Similarly, Part II argues that the judiciary can no more reliably check majoritarian institutions than they can check one another and in some ways, by its very nature, is a less effective check than they. Tushnet does not define legislative tyranny, but the examples he gives-including runaway budget deficits and resource allocations objectionable to one or another ideological group-lead one to conclude that the inability of judicial review to scotch legislative tyranny is neither remarkable nor, on balance, regrettable. A general criticism that emerges from the discussion in Parts I, II, and III is that Tushnet's "impossibility theorem," despite its elegant symmetry, suffers grievously from the amorphousness of its component concepts: tyranny, self-interest, the liberal tradition. If indeterminacy is a fatal deficiency in a constitutional theory, it is no great virtue in a constitutional metatheory either.

Part III examines the historical relationship between liberalism and judicial review and rejects any notion that either the framers themselves or liberal political thinkers of their era relied heavily on judicial review for salvation from legislative tyranny. The seventeenth and eighteenth century political theorists usually associated with the liberal tradition were either silent or negative on the subject of judicial review. Further, even the generic concept of intragovernmental constraints - the doctrine of checks and balances-long antedates liberalism and has been far more closely associated with the civic republican than with the liberal tradition. Finally, the "Hobbesian" vision of passionately selfish human nature was, in one degree or another, common intellectual currency in the seventeenth and eighteenth centuries, shared by republicans and liberals alike, tempered even among liberals by a recognition of human sociality, and, as Tushnet acknowledges, not embraced, at least in strong form, by the framers themselves. Tushnet, doubtless aware of these difficulties, insists that the "liberal tradition," as he uses the phrase, is located not in the works of systematic political thinkers but in "amateur political theory" 
and experienced in the culture"20 This evasive approach, however, is unconvincing, in view of Tushnet's failure to identify the "amateur" theorists in question, to indicate clearly what he means by liberalism-as lived-in-the-culture, or to explain in what sense the American culture can be said to rely upon the institution of judicial review to perform a role it is manifestly ill-equipped to perform.

Part IV examines and rejects Tushnet's claim that in a truly republican America, with decentralized institutions and a politics of civic virtue, judicial review and constitutional theory would cease to be necessary. The thrust of the argument is that most of the burning constitutional issues of our time would present the same highly controversial face to a republican society; a politics of civic virtue would not make those issues go away or evoke a significantly different pattern of legislative responses. Miniaturizing political units, moreover, would not produce a politics of unanimity, even at the local level, without strong informal coercion, and local unanimity would in no event affect the need for constitutional safeguards against the actions of higher-level government units or for the benefit of local newcomers not part of the original consensus. Finally, any argument that the substitution of a public-interest for a private-interest perspective at the political and legislative levels would make judicial review redundant, ignores the traditional insights that republican attitudes and institutions are ever vulnerable, that civic virtue can be lost and is always at risk, and that a judicially enforceable constitution is one means of holding back these tides of change.

\section{Constitutional Theory and Judicial Tyranny}

The framers of the Constitution did not fear judicial tyranny. Hamilton, in Federalist No. 78, described the judicial as the branch "least dangerous to the political rights of the Constitution" and "beyond comparison the weakest of the three departments of power." Liberty, he declared, "can have nothing to fear from the judiciary alone."21 Even the opponents of the Constitution, with one notable exception, expressed little concern about judicial review. One historian has noted "the almost complete absence of debate over judicial review" during the ratification period. ${ }^{22}$ Only Robert Yates, whose essays in a New York newspaper over the signature of "Brutus" were among the most influential of the Antifederalist writings and the immediate trigger for

\footnotetext{
20 Id. at 13 n.35.

${ }^{21}$ The Federalist, supra note 1 , at No. 78 (A. Hamilton).

22 C. Kenyon, The ANTIFederalists lxxxvii (1976).
} 
Hamilton's response, strongly criticized this aspect of the proposed judicial power on the ground that the Supreme Court's interpretations of the Constitution would be beyond popular control, but even he seemed more afraid that the Court would legitimize congressional encroachments on the states than that they would initiate encroachments of their own. ${ }^{23}$ The fact that other Antifederalists, usually quick to sound the alarm, did not follow his lead even after Hamilton had joined issue is evidence that they saw no threat in judicial review. ${ }^{24}$

Tushnet is convinced the framers and their opponents were shortsighted. He believes that their cozy expectations, based on the republican tradition, of a civically virtuous judiciary interpreting a readily understood constitution transgressed only occasionally by an almost equally virtuous Congress were overtaken by the dynamics of capitalist expansion. But even Tushnet has difficulty taking the threat of judicial tyranny seriously, at least in comparison to the threat of legislative tyranny. He observes that:

[O]ne would be hard pressed to defend the claim that in contemporary society more tyranny is exercised by willful judges than by willful legislators. If the current complaints of selfstyled conservatives are taken as a measure of judicial tyranny the instances that they identify [abortion, school prayer, busing], with one exception, pale in comparison. ${ }^{25}$

And even in that exception, the case of abortion, the Court may only have done what state legislatures were in the process of doing anyway.

\section{A. Constitutional Theory as Constraint}

In Tushnet's analysis, "judicial review plays a central role, as a method of controlling exercises of legislative power" and "[c]onstitutional theory plays a similar role, as a method of controlling exercises of judicial power."26 This notion that constitutional theory stands to judicial review as judicial review stands to legislation is misleading. Constitutional theory, unlike judicial review, is not an external institutional check. No higher authority enforces its terms; no legal consequences attach to its violation. It is a body of advisory opinion, furnishing courts with guidelines and prescriptions they may or may not choose to adopt. It is in many (though not all) ways analogous to the

23 See $i d$. at $338-57$.

24 See id. at lxxxviii.

${ }^{25}$ M. TuSHNET, supra note 2 , at 28 , n.28.

${ }^{26} I d$. at 147. 
guidance that political theory, economic theory, or social theory provides to legislators. The theoretical writings of John Hart Ely are no more (and no less) "constraints" upon the Supreme Court than those of John Stuart Mill, John Maynard Keynes, or John Rawls are upon the Congress. Tushnet's suggestion that constitutional theory "constrains judges by providing a set of public criteria by which theorists, interested observers, and the judges themselves can evaluate what the judges do,"27 implies that such evaluators might function as an external check. But legislatures, too, have professional critics-legions of them. And these critics, unlike those who monitor the performance of federal judges, can sometimes make the difference between retention and loss of office. There is no reason to think that the pages of the Harvard Law Review carry greater weight, even as a source of informal suasion, with the judiciary than the editorial pages of the New York Times carry with other federal actors. Indeed, if judges were as Hobbesian in their motivation as Tushnet thinks liberalism assumes, no constitutional theory, however constraining on paper, would give them much pause: men and women hungering for material gain would scarcely be deterred by the censure of professors.

Constitutional theory, moreover, does not speak exclusively to courts; it is addressed to legislators and other governmental actors as well. The constitutional theory that told the courts that the fourteenth amendment should be interpreted as protecting non-textual rights of a "fundamental" character, and that abortion was one such right, delivered that same message to legislatures; the courts were advised not to enforce, the legislators not to enact, abortion laws. Similarly, the constitutional theory holding that the fourteenth amendment did not enact Herbert Spencer's Social Statics instructed courts and legislatures alike that the Constitution was no impediment to the regulation of economic activity. Even those propositions of constitutional theory that specify the nature and magnitude of the public interest that is necessary to justify the curtailment of a particular right-propositions that might superficially appear relevant only to reviewing courts-likewise indicate to legislators what is expected of them (just as standards of proof in civil or criminal litigation are of use to triers of fact, not merely to reviewing courts).

The point is more than a formal quibble. It raises a serious question as to the plausibility of Tushnet's repeated assertions that liberalism depends on constitutional theory to "constrain" judges. If it does so depend, it is not relying on checks and balances, but on what used to 
be called, in a phrase that now seems almost quaint, "judicial self restraint." Judges who lack that quality will be prone to excess no matter what constitutional theorists preach to them. Those who have it make responsible judgments duly sensitive to the prevailing democratic values of the society, and consequently the proper limits of their own office, even without the formal and highly specific theoretical guidelines that Tushnet seems to think the liberal tradition demands. In an important sense, "self-restraint" is merely another phrase for "civic virtue" in the exercise of judicial review. Tushnet himself maintains that where civic attitudes prevail, hard and fast formal rules are unnecessary to contain official power. The same, I submit, is true of judicial self-restraint in its relationship to constitutional theory. To the extent that Tushnet's paradigmatic liberal wants more, wants formal specificity, he is a strawman.

\section{B. Other Constraints}

In emphasizing that constitutional theory functions primarily as an internal rather than as an external constraint, I do not mean to denigrate its importance as a source of guidance to those judges who (contrary to Tushnet's "liberal" paradigm) wish to be guided. But demoted to the status of an internal constraint, constitutional theory is but one of many factors, both internal and external, of varying strength, that operate to reduce the frequency and impact of countermajoritarian court decisions, especially those likely to be bitterly resented. The very fact that five votes are required for a Supreme Court decision is already an internal constraint of no small practical significance in a body of independent-minded individuals, not driven by party whip or disciplined by executive hierarchy, who do not generally see themselves as a "team" acting cooperatively to advance a common program or agenda. That the Court ordinarily is composed of members selected by several Presidents over the course of decades rather than by a single President all at once makes for diversity of opinion and further reduces the likelihood that the Court will become a runaway engine. In addition, quite apart from any substantive doctrinal rules that may be provided by constitutional theory, non-substantive doctrines of self-limitation deeply imbedded in the institutional practice of the Court further slow it down. Among these, of course, are the doctrines of stare decisis, case or controversy, ripeness, abstention, political question, and all the other devices of "not doing" that Alexander Bickel referred to as "the passive 
virtues."28 $^{\text {,28 }}$

Beyond these institutional mechanisms are constraining social and political realities, both internal and external. Tushnet stresses repeatedly that "judges are not that different from legislators in terms of gross demographic characteristics." They are "mostly male, mostly highly secularized, mostly white, mostly rich, mostly old, all lawyers, mostly owners of stock, almost never members of labor unions, mostly tolerant of moderate use of some mind-altering drugs but not others, mostly heterosexual, and so on."29 These demographics make them a weak safeguard but also a weak threat. Tushnet finds "compelling" the conclusions of political science that "in the medium-to-long run judicial review doesn't matter very much"; that most of the time "judicial review does little more than ease the burden on those who wish to take obsolete statutes off the books"; and that even then, "controversial Supreme Court decisions will be implemented fully only under special circumstances, for example, when sympathetic bureaucracies are charged with the task of implementation." In sum, "[i]t seems that Supreme Court decisions make a difference when contemporary majorities or near-majorities want them to make a difference."30 Our political system, moreover, contains a number of external institutional constraints against judicial excess: impeachment; constitutional amendment; new (and, perhaps, wholesale) judicial appointments; control over the Court's jurisdiction; funding restrictions. Tushnet argues that the effectiveness of these constraints is limited, especially in the short term, and his conclusion is that "the insights of political science cannot allay concern about judicial tyranny."3I

Tushnet's discussion of political realities suggests that the effects of judicial review, for better or worse, will be felt primarily in the shortterm; in the long run, majorities will get what they want. If so, the danger of judicial tyranny-to the extent it lies in or depends on the countermajoritarian character of court decisions-is greatly mitigated. For one thing, some of the more potent constraining factors mentioned by Tushnet-the demographic similarity between legislators and judges and the tendency not to enforce or comply with strongly unpopular court decisions-operate to reduce both the frequency and impact of judicial interventions even in the short term.

Second, in those instances where countermajoritarian decisions are rendered and enforced-producing results ultimately correctable by the

28 A. Bickel, The Least Dangerous Branch 112 (1962).

29 M. TuSHNET, supra note 2 , at $120,184$.

${ }^{30} \mathrm{Id}$. at $197-98$.

31 Id. at 201. 
majority but only after damage has been done-the term "tyranny" seems quite inappropriate. Such action might better be described as the exercise of a "suspensive veto," preserving the status quo until the body politic has had a sufficient opportunity for second thought. ${ }^{32}$ This "cooling-off" function is precisely the one anticipated by the framers, not only for judicial review, but also for other institutional arrangements designed to prevent overhasty decisions by the popular branch. ${ }^{33}$

In terms of their relationship to the long-term preferences of the political majority, Supreme Court decisions invalidating statutes fall into one of four categories. Some decisions accelerate outcomes that the majority would eventually have brought about anyway. Some decisions achieve outcomes that the majority will come to accept, favor, or perhaps even build upon but could not have brought about on its own. Some decisions delay outcomes that the majority will insist upon and reestablish. Finally, some decisions produce outcomes that the majority disfavors and will continue to disfavor, but with insufficient intensity or insufficient numbers to be able to "override" the Supreme Court's "veto." In the first two situations judicial review actually furthers the majority's long-term preferences. In the third, it postpones their effectuation pending sober reconsideration-hardly the stuff of which tyranny is made. It is only in the last situation-one which Tushnet seems

${ }^{32}$ The suspensive veto analogy is not confined to cases-perhaps infrequent-in which the statute declared unconstitutional is of recent enactment. It applies also in cases where a statute long-entrenched, and perhaps uncontroversial when originally enacted, has become a matter of controversy under evolving societal values. Here, too, judicial review suspends the operation of the now suspect statute until a new majority has had an opportunity to reconsider, free from the inertial compulsion of the statute on the books, how much of the previously established policy or practice it insists upon preserving. In such cases, to be sure, the phrase "cooling-off" is inappropriate.

33 Hamilton foresaw that an independent judiciary would guard against those "ill humors" which "though they speedily give place to better information, and more deliberate reflection, have a tendency, in the meantime, to occasion dangerous innovations in the government, and serious oppressions of the minor party in the community." THE Federalist, supra note 1 , at No. 78 (A. Hamilton). In a similar vein, Hamilton defended the presidential veto by reminding that "impressions of the moment may sometime hurry [the legislature] into measures which itself, on maturer reflection, would condemn," id. at No. 73 (A. Hamilton), and a four-year term on the ground that it would give the President the independence needed to resist "the humors of the legislature," in that the republican principle, while demanding that "the deliberative sense of the community should govern the conduct" of the people's representatives, "does not require an unqualified complaisance to every sudden breeze of passion, or to every transient impulse" the people may receive. Id. at No. 71 (A. Hamilton). Likewise, Madison, arguing for the necessity of the Senate, noted that while "the cool and deliberate sense of the community" ought and would ultimately prevail, "there are particular moments in public affairs when the people, stimulated by some irregular passion, or some illicit advantage, or misled by the artful misrepresentation of interested men, may call for measures, which they themselves will afterwards be the most ready to lament and condemn." Id. at No. 63 (J. Madison). 
to think rare-that the will of the majority, by hypothesis a weak one, is indefinitely frustrated. To the extent the tyrannical character of judicial action is a function of its offensiveness to majoritarian values, judicial tyranny seems a relatively modest hazard.

\section{G. Judicial Tyranny: A Chimera?}

The preceding section has argued that the danger of "judicial tyranny," whatever that might mean, is mitigated by a number of internal and external factors, of which constitutional theory is but one. The seriousness of the danger, as mitigated, depends to a considerable extent on what one understands by "judicial tyranny." Much of what was just said in the preceding section implies that judicial action is "tyrannical" in whole or in part by virtue of its countermajoritarian character. It would be wrong to suppose, however, that in Tushnet's mind, "tyrannical" and "countermajoritarian" are synonomous or closely-linked concepts.

Tushnet does not define "judicial tyranny" except through the use of vague synonyms such as "extreme judicial behavior" and "judicial misbehavior." ${ }^{\prime 34} \mathrm{He}$ does, however, give examples, all from the viewpoint of "self-styled conservatives": the abortion, school prayer, and busing decisions. ${ }^{\mathbf{3 5}}$

What makes these decisions tyrannical Tushnet does not explain: But it does not appear to be solely or primarily their countermajoritarian character. ${ }^{36}$ Tushnet appears nowhere near as worried about the "countermajoritarian difficulty" as most other critics of non-originalist constitutional theory. He rejects the affirmative arguments for repre-

34 M. Tushnet, supra note 2, at $180,185,186$.

${ }^{35}$ Id. at 28 n.28.

${ }^{36}$ On a scale that measured the strength of the popular opposition to the Court's decision, along with degree of justification for it in such "hard" sources as the constitutional text, the intent of the framers, or (perhaps) democratic theory, two of the three examples cited by Tushnet (busing being the possible exception) do not seem egregiously contermajoritarian. The extent to which school prayer is a practice supported by strong popular majorities is unclear and doubtless locally variable; and the Court's invalidation of it was based on an interpretation of specific language in the first amendment at least somewhat supported by legislative history and the across-the-board prohibitions contained in the old-fashioned abortion statute invalidated in Roe v. Wade, 410 U.S. 113 (1973), do not seem to have great popular appeal today, so that Roe does not present the combination most offensive to majoritarians: a highly popular statute struck down on non-originalist grounds. Judicial decisions ordering busing to achieve school racial balance are highly unpopular, even in many black communities, and the grounds for them are less than compelling even under a representation-reinforcement theory of judicial review. See Goodman, Some Reflections on the Supreme Court and School Desegregation, in RACE AND Schooling IN THE CITY 45, 71 (A. Yarmolinsky, L. Liebman, C. Schelling eds. 1981). But see Fiss, The Jurisprudence of Busing, 39 Law and Contemp. Probs. 194, 210-11 (1975). 
sentation-reinforcing review on the ground that they "rest on a narrow and probably indefensible conception of democracy,"37 a conception that "has seemed inadequate to most political theorists, who argue that democracy, properly conceived, requires the protection of some fundamental but nonpolitical rights." 38 And, his rejection of non-originalist review grounded in moral philosophy and on the distinction between fundamental and non-fundamental rights does not rest on majoritarian grounds. It rests instead on the inability of moral philosophy to provide constraining guidance on moral and legal issues at the concrete level at which judges must decide, and, additionally, on the fact that judges are no more, and may be less, competent moralists than legislators because they know less about the effects of their decisions on the lives of real people. ${ }^{39}$ The role of elections in conferring legitimacy is not even mentioned. One senses that Tushnet would be willing to classify these three decisions as tyrannical (from the perspective of the right, of course), even if they had been made by legislators rather than judges. ${ }^{40}$ It is not the use of power by countermajoritarian institutions that troubles him so much as the use of coercive power, even by majoritarian institutions, without the consent of the coerced. It is ironic (if I am right in this impression) that a self-proclaimed socialist like Tushnet should hold the same view of the legitimacy of government as a radical libertarian like Robert Nozick. ${ }^{41}$

A more convincing explanation for the selection of Tushnet's three examples of judicial tyranny, and for the deep feeling of resentment admittedly aroused by each of them, is that each decision arguably deprives the group adversely affected of a right they (or their defenders) deem fundamental: the fetus's right to life, the schoolchild's right not to be assigned to school on the basis of race, and the child's right to pray in school, or at least not to be denied that opportunity while comparable secular exercises are permitted. Some years ago, Robert Dahl found implicit in Madison's The Federalist, No. 10 a definition of tyranny as "every severe deprivation of a natural right." ${ }^{\text {"42 }}$ Although the MadisonDahl definition (hereafter, simply "Dahl's definition") is not explicitly embraced by Tushnet, it probably captures his tacit meaning. Its impli-

37 Id. at 72 .

38 Id. at 71,72 .

39 See id. at 121 .

to See infra notes 67-70 and accompanying text (discussing Tushnet's expansive definition of legislative tyranny).

${ }^{4}$ See R. Nozick, ANarchy, State, and Utopia (1974).

42 R. Dahl, A Preface to Democratic Theory 6 (1956). Dahl himself concluded that this definition, and indeed the very concept of majority tyranny, has no operational meaning. See id. at 22-24. 
cations, therefore, are worth examining.

An initial question is the status, under Dahl's definition, of judicial actions that would clearly be non-tyrannical if done by a legislature but, by nullifying decisions arrived at through the democratic political process, could be seen as violating the right of citizens to participate in that process. John Locke drew a distinction between "usurpation," which he defined as "the exercise of power, which another hath a right to" and "tyranny," which is "the exercise of power beyond right, which no body can have a right to." 43 To the extent "judicial tyranny" includes decisions that are objectionable only because a court rather than a legislature made them-instances of what Locke called "usurpation" and modern parlance refers to as "judicial legislation"-Tushnet's tyranny analysis becomes little more than a restatement of the standard countermajoritarian objection to judicial review, an objection he seems relatively uninterested in making and to the understanding of which his book contributes little.

Let us therefore proceed on the assumption that Dahl's definition, as Tushnet would apply it, excludes instances of mere "usurpation" in Locke's sense and includes only decisions that would be tyrannical even if made by a legislature. The next question is whether Dahl's "natural rights" are confined to negative rights to be free from government interference or discrimination, or whether they also include affirmative claims on government for assistance or protection. If the former, the opportunities for tyranny through the exercise of judicial review would be few and far between. Not only must courts wait for cases to come to them, but in declaring a statute unconstitutional they nearly always leave the situation in statu quo ante, with the adversely affected parties no worse off, and their negative rights no more impaired, than if the legislature had done nothing. The most obvious exceptions are cases in which the court goes beyond merely declaring a statute unconstitutional and prescribes affirmative action (busing) to remedy the violation of one right (nonsegregation), only to have that action perceived in turn as violating another (colorblind treatment by the state). ${ }^{44}$ Such exceptions aside, the important generalization is this: If tyranny is the use of coercive power by the state against the negative rights of the individual, judicial review will far more often involve the restraint of that power

$43 \mathrm{~J}$. Locke, Two Treatises of Government at II, § 199, at 446 (P. Laslett ed. 1963).

14 On this negative view of rights, the abortion case certainly would not qualify as tyranny under Dahl's definition, and the prayer case would be problematic, depending on whether the right allegedly violated by the Court is the affirmative right to pray in school or the right not to be discriminatorily excluded while arguably comparable nonreligious expressions of conviction are permitted. 
than the exercise of it. Indeed, judicial tyranny is more likely to be encountered in cases of statutory construction, in which a court adopts an expansive interpretation of a regulatory law or adds a coercive judge-made remedy to those explicitly provided by the legislature, than in constitutional cases. The fact that such statutory decisions are in principle capable of correction by the legislature may not be much comfort if the familiar forces of legislative inertia are at work to block that correction.

The range of potential judicial tyrannies widens dramatically, however, if natural rights are taken to include affirmative claims on the state for assistance in meeting basic needs and for protection against discrimination or deprivation by fellow citizens. For, in this affirmative view, there are countless statutes that could be seen as declarative and protective of people's natural rights-rights against crime or private discrimination, rights to a living income, a clean environment, a safe workplace, decent housing, a minimal education, adequate health care, and so on. A judicial decision overturning such legislation-like a statute repealing it or legislative failure to enact it in the first place-could be seen, under Dahl's definition (still assumed to be Tushnet's), as a tyrannical act (or omission).

For example, the Dred Scott decision ${ }^{45}$ and the Civil Rights Cases of $1883^{46}$ struck down statutes protecting blacks from slavery and discrimination, respectively; both were tyrannical on the assumption that blacks were morally entitled to the statutory protection thus removed. And if one assumes that the bakery workers in Lochner $v$. New York ${ }^{\mathbf{4 7}}$ were entitled as a matter of fundamental right to the workplace protection afforded them by New York's maximum hours law, the Supreme Court's decision invalidating that law would qualify as an instance of tyranny. And the same reasoning would apply to countless other decisions striking down economic regulations during the Lochner era.

The cases just cited have all been overruled or otherwise superseded. ${ }^{48}$ But there are modern examples as well. Roe $v$. Wade ${ }^{48}$ voided

45 Dred Scott v. Sanford, 60 U.S. (19 How.) 393 (1857).

46109 U.S. 3 (1883).

47198 U.S. 45 (1905).

${ }^{48}$ Dred Scott was superseded by the thirteenth amendment. See U.S. ConsT. amend. XIII; the Civil Rights Cases, at least in part, by later decisions upholding on alternative grounds a federal public accommodations statute almost identical to the one formerly invalidated. See Katzenbach v. McClung, 379 U.S. 294 (1964); Heart of Atlanta Motel v. United States, 379 U.S. 241 (1964); Lochner and progeny were long since moribund when explicitly declared dead in Lincoln Federal Labor Union v. Northwestern Iron and Metal Co., 335 U.S. 525, 536 (1949).

4910 U.S. 113 (1973). 
statutes protecting fetal life; New York Times $v$ Sullivan, ${ }^{50}$ a statute protecting reputation; Hudnut $v$. American Booksellers Association, ${ }^{51}$ a statute protecting women from debasement by pornography. Furthermore, decisions under the establishment-of-religion clause, banning prayer $^{62}$ from the public schools and state aid to parochial schools, ${ }^{63}$ could be regarded as tyrannical in that they discriminate against religious ideas, religious exercises, and religious institutions vis-a-vis their secular counterparts. All these situations are reasonable candidates for affirmative natural rights.

Yet even among those who accept in the abstract a Dahl-type definition of tyranny and its application to affirmative natural rights, I suspect that few would be intuitively inclined to characterize most of the above decisions as instances of judicial tyranny. For some, failure to satisfy Dahl's qualifier-"severely"-might be enough to explain this intuition. For others, it might be the fact that many of the cited decisions, such as the speech and religion cases, represent efforts by the Court to define the contours of specific constitutional guarantees rather than to make up rights of its own. More importantly, almost by definition, candidates for judicial tyranny are cases in which competing claims of fundamental right are advanced on both sides: fetal life against maternal autonomy, reputation or womanly dignity against free speech, freedom from present anti-white racial discrimination against freedom from the consequences of past anti-black racial discrimination; freedom of religion against freedom from religion. Charges either of judicial tyranny or of the judicial sanctioning of legislative tyranny will be leveled regardless of which decision the court makes. In such cases, where the deprivation of a right claimed to be fundamental is strictly unavoidable given the absence of consensus, the use of the term "tyranny" to describe that deprivation abuses the language.

\section{The Self-Interest Factor}

One other factor, however, might be considered to justify the classification of these or other Supreme Court decisions as tyrannical: the self-regarding motivation of the judges who made them. The self-interest factor plays a key role in Tushnet's analysis, both at the judicial and legislative levels. To avoid repetition, it will be useful to discuss

51475 U.S. 1001 (1986) affg 771 F.2d 323 (7th Cir. 1985).

s2 Wallace v. Jaffree, 472 U.S. 38 (1985); Engel v. Vitale, 370 U.S. 421 (1962).

ss See, e.g., Aguilar v. Fenton, 473 U.S. 402 (1985); Lemon v. Kurtzman, 403 U.S. 602 (1971). 
both levels at this point rather than in separate sections.

Tushnet does not specify exactly what connection he sees between self-interested motivation, whether on the part of legislators or judges, and tyranny, legislative or judicial. The connection could either be causal (selfish legislators or judges are more likely to commit acts of tyranny, independently defined, than civically virtuous ones) or conceptual (self-interested motivation is part of the very definition of tyranny). The empirical validity of the causal connection is open to question. In the case of judges, the selfless ideologue is at least as likely to engage in egregious countermajoritarian action as the self-regarder, who may believe his interests better served by going along with the majority. In the case of legislators or other political actors, the causal hypothesis is equally problematic. It is not obvious that a pluralistic politics of competition and accommodation among interest groups is more conducive to repression, intolerance, and dictatorship than a politics of civic virtue and unbending devotion to principle and the collective good. History is bloody with examples of virtuous oppression in the name of a faith, a nation, an ideology transcending self. The Ayatollah's Iran is only the most recent. Robbespierre epitomized the point when, speaking for the Committee of Public Safety in 1794, he expounded the principles of political economy that were to guide the revolutionary government: "If the basis of popular government in time of peace is virtue, the basis for popular government in time of revolution is both virtue and terror: virtue without which terror is murderous, terror without which virtue is powerless." 34 By saying this, I do not mean to engage in the virtuebashing that may be coming into vogue but merely to point out that a causal relationship between self-interest and repression, or between civic virtue and tolerance, cannot be assumed lightly.

There is perhaps greater plausibility in the conceptual connection between self-interest and tyranny: Legislative or judicial conduct that would not otherwise fairly be characterized as tyrannical deserves that characterization when motivated by desire for personal or class advantage. Such an approach has standing in the liberal tradition. Locke himself defined tyranny as the "use of power any one has in his hands; not for the good of those who are under it, but for his own private separate advantage." ${ }^{\text {"s5 }}$ Locke, however, clearly did not have in mind the ruler who acts in accordance with the interests and desires of a majority of his subjects though to the detriment of a minority. Tushnet clearly does. That the motives of a legislature may properly be weighed

s4 R.R. Palmer, Twelve Who Ruled 276 (1969) (quoting Robbespierre's speech of February 5, 1794).

ss J. LOCKE, supra note 43, at II, § 199, at 446. 
in a moral evaluation of its action would be conceded by almost everyone. Few, however, would accept the proposition that self-interest on the part of legislators, including that of gaining re-election by serving the interests and preferences of a majority of their constituents, converts all their coercive and felt-as-coercive action into tyranny.

In the case of judicial tyranny-the subject that immediately concerns us-the self-interest factor is particularly elusive. Life-tenured judges do not, in any direct sense, "represent" the interests of constituents or depend upon them for their jobs. To accuse them of pervasive self-regarding behavior is thus counter-intuitive. Yet Tushnet clearly does claim that in liberal theory, and in American reality, judges, like everyone else, are motivated by self-interest rather than public interest; and he links this "fact" to the problem of judicial tyranny. He says that the framers, as liberals "had no reason to think that judges would be any less attached to possessive individualism than were the representatives whom the judges were to restrain." Judicial review "thus substituted the threat of tyranny by the judges for the threat of tyranny by the legislators." 56 The framers "had to explain why judges would not be purely self-regarding-out to maximize their personal power-or indirectly self-regarding-out to promote the interests of narrow groups with which they were affiliated." Their answers, drawn from the republican tradition, "were that judges, like others in the national government, would 'discern the true interest of their country' because they were selected from a nationwide pool and were given guarantees of tenure that assured that they would interpret the Constitution responsibly." "57 These answers, however, were "invalidated" by the "framers' commitment to private property," as judicial appointments became "politically sensitive matters" and the republican idea that the Constitution has a "plain meaning" became implausible. ${ }^{.8}$

But what is the historic evidence that the framers' "answers" were "invalidated"? What is the evidence that the Supreme Court, when exercising judicial review, has behaved in a self-regarding manner? One would be hard put to find it in the three examples of putative judicial tyranny cited by Tushnet himself. Although millions of Americans regard Roe $v$. Wade as an act of usurpation, and a serious human rights violation to boot, scarcely anyone has suggested that a single member of the Court, on either side, cast a self-interested vote. Nor is self-interest obvious in the busing and school prayer decisions. Indeed, the desegregation and abortion cases yielded results precisely the opposite of those 
that a Hobbesian cynic would have predicted from a Court overwhelmingly composed of white males. ${ }^{59}$

This is not to deny that those decisions could be criticized on other grounds having to do with the limitations of the judicial perspective. It could fairly be argued that the abortion and prayer decisions reflect a secularist and modernist "bias" insufficiently sensitive to the claims of religion and traditional morality. In the desegregation debates, one frequently hears the complaint that courts would not issue burdensome busing orders if their own children were subject to them. The objection here is not one of self-interest; indeed, the point seems to be that the Court had too little stake in the outcome. Instead, the objection is a particularly focused version of the widely-voiced complaint of judicial elitism: that federal judges, especially those who sit on the Supreme Court, are not demographically representative enough, just as they are not politically accountable enough, to justify the coercive imposition of their values on others who do not share them.

But bias and elitism are not self-interest: An elite, even an elitist, judiciary may nevertheless be capable of unfailing civic virtue. Indeed, permanency of tenure, the very device designed by the framers to liberate federal judges from the pressures of politics and the temptations of self-interest, sets them apart from ordinary people and the insecurities that shape their lives and values. The Olympian perspective that makes civic virtue possible for the Court makes elitism, or at least the appearance of elitism, inevitable. ${ }^{60}$

It will be recalled that the three examples of "judicial tyranny" cited by Tushnet were all chosen from the viewpoint of "self-styled conservatives." The perspective of "self-styled liberals" might have yielded more suspicious examples of possible self-regarding judicial be-

${ }^{89}$ But see Bell, Brown v. Board of Education and the Interest-Convergence Dilemma, 93 HARv. L. REv. 518, 524-25 (1980) (arguing that Brown was in part a prudential decision serving the interests of whites as well as blacks because it enhanced American credibility among peoples of the emerging third world, provided needed reassurance to potentially rebellious former black servicemen, and removed a barrier to further industrialization of the south).

60 Nor would the problem be solved by a revival of the republican tradition. The English republican tradition of the eighteenth century was elitist to the core. It was an ideology of landed gentry who believed they had a special calling to manage the affairs of state and were loathe to share that task with the newly enriched bourgeoisie, let alone with wage-earners. See infra note 139 and accompanying text. And even in the more egalitarian climate of America, civic virtue was associated in many minds, including Madison's, with the idea of a natural elite who would be chosen by the people to represent them at the national level and who would be able to rise above the spirit of factionalism in which local and state political figures were enmired. Present-day advocates of a republican revival obviously have no wish to preserve that aspect of the tradition, but slaying the dragon of elitism would not be easy. It is not self-evident that civic virtue without elitism is possible. 
havior. Decisions invalidating state affirmative action plans, ${ }^{61}$ for instance, could be seen as reflecting a greater empathy with the white displacees than with the black beneficiaries of the program. Hudnut $v$. American Booksellers Association, ${ }^{62}$ in holding a state anti-pornography statute violative of the first amendment, might reflect an identification with the male readers of pornography or, short of that, an insensitivity to the interests of the women offended by it (whether these would be charges of bias or of self-interest could depend on the precise formulation).

Such motives and attitudes however, are, for me at least, difficult to square with the Court's overall record in racial discrimination, or even affirmative action, cases; in gender cases (in most of which it found discrimination); and in first amendment cases (in many of which it protected the rights of hated speakers with whom the Justices could not possibly have sympathized). Thus, even in the decisions adverse to the groups under-represented on the Court, I see no convincing evidence of self-interested decision-making. If the fear of judicial tyranny depends on the assumption that judges are Hobbesian actors, that fear is largely groundless.

Tushnet's "Hobbesian hypothesis" not only is probably false; if true, it would have highly subversive implications for Tushnet's own analysis. A fundamental assumption of Red, White, and Blue is that a constitutional theory that provided determinate and uncontroversial guidelines would constrain judges in the exercise of judicial review. If judges, along with everyone else, really were Hobbesian egoists, insatiably hungry for wealth and power, no constitutional theory, however paper-perfect, could possibly restrain them. Just as Hobbesian legislators could disregard the Constitution, so Hobbesian judges could disregard both the Constitution itself and, with far less compunction, the non-authoritative, ultimately self-imposed limitations of constitutional theory.

Tushnet's answer might be that if only constitutional theory could give us definite and uncontroversial guidelines, "theorists" and "interested observers" would rally behind them and even Hobbesian judges would be forced to obey in order to avoid condemnation. But the assumption that possessive individualists, hell-bent on maximizing their wealth and power, would be deterred by professional criticism is laughable. Such obedience would be consistent with the hypothesis of selfregarding judicial motivation only if self-interest is expansively under-

${ }^{61}$ See City of Richmond v. J.A. Croson Co., 109 S.Ct. 706 (1989); Wygant v. Jackson Bd. of Educ., 476 U.S. 267 (1986).

${ }_{62} 475$ U.S. 1001 (1986), aff 771 F.2d 323 (7th Cir. 1985). 
stood to include the desire for praise and approval, honor and respect, fame and glory - in a single word, reputation.

This domestication of "self-interest" is not altogether incompatible with a "Hobbesian" approach. Hobbes himself recognized that "[D]esire of praise disposeth to laudable actions, such as please them whose judgments they value" and that "[D]esire of fame after death does the same."63 Moreover, concern for reputation seems a far more realistic hypothesis about what makes life-tenured federal judges tick than desire for additional wealth or power.

The trouble with using a watered-down notion of self-interest, however, is that it now becomes hard to tell the difference between selfregarding and virtuous motivation. A judge who cares only to achieve a deserved reputation for integrity, intellectual honesty, and civic virtue would behave in much the same way as one, indifferent to reputation, whose every action is a natural expression of those same qualities. I wonder whether one would find many judges in the latter category even in a republican society and (probably the same wonder) whether the concept of civic virtue in the republican tradition ever really excluded the former. The Aristotelian conception of man as essentially a political being, acting for the common good as an expression of his basic human nature, and without thought of self-advantage of any kind, was not the only, or even perhaps the primary, explanation for civic virtue in the republican tradition. Machiavelli, for example, has been interpreted as holding that patriotism and devotion to the public good-in short, civic virtue-was not an end in itself but the means by which the leaders of a republic sought to secure the strength and freedom of the state and ultimately their own reputation in the eyes of the world and of posterity. ${ }^{64}$ The British commonwealthmen of the eighteenth century made a similar connection between civic virtue and love of fame:

Every passion, every view that men have, is selfish in some degree; but when it does good to the public in its operation and consequence, may be justly called disinterested in the usual meaning of the word. So that when we call a man disinterested, we should intend no more by it, than that the turn of his mind is towards the public, and that he has placed his own personal glory and pleasure in serving it. ${ }^{65}$

e3 T. HobBes, Leviathan pt. I, at 80-81 (Everyman's library 1950).

64 See Skinner, The Idea of Negative Liberty: Philosophical and Historical Perspectives, in Philosophy and History 193, 205 (R. Rorty, J.B. Scheewind \& Q. Skinner eds. 1984).

${ }_{63} 2 \mathrm{~J}$. TRenchard \& T. Gordon, Cato's LetTers, or Essays on Liberty, Givil. OR Religious, AND OTHER IMPORTANT SUBJECTS 52 (1733). 
Indeed, "[t]his passion topped all others in the eighteenth century hierarchy of passions, since it was the only one to comprehend private and public, individual and general interest." ${ }^{\text {"66 }}$ Similarly, Douglas Adair, in a brilliant essay examining the framers' motivations, emphasizes the importance of their conception of glory, honor and fame. ${ }^{67}$ According to Adair:

[T] he greatest and the most effective leaders of 1787 - no angels they, but passionately selfish and self-interested men - were giants in part because the Revolution had led them to redefine their notions of interest and had given them, through the concept of fame, a personal stake in creating a national system dedicated to liberty, to justice, and to the general welfare.

The "love of fame the ruling passion of the noblest minds" thus transmuted the leaden desire for self-aggrandizement and personal reward into a golden concern for public service and the promotion of the commonwealth as the means to gain glory. The desire for fame operated thus as a constant goad in the political behavior of the mature Washington, of Adams, of Jefferson, Hamilton and Madison. ${ }^{68}$

In short, if the self-interest that Tushnet attributes to the American federal judiciary turns out to be nothing more or less than a desire for respect and approval of professional peers or of the public at large, it is a motive barely if at all distinguishable from civic virtue and hardly the stuff of which tyranny is made.

The argument that professional scrutiny would be an effective check against self-interested judicial review if only the applicable constitutional standards were sufficiently definite encounters another difficulty. It assumes that the theorists and interested critics are themselves unmotivated by private interest, or that their particular interest (professional distinction and advancement) coincides with the public good-in short, that the kibitzers are more virtuous than the players. In a Hobbesian world, this is a precarious assumption. If it is true that the professional interests of the "theorizing community" would lead its members to adopt the perspective of the public good, why should that be less true of members of the Supreme Court, who come from the

66 G. Stourzh, Alexander Hamilton and the Idea of Republican GovERNMENT 106 (1970). 1974).

e7 See D. Adair, Fame and the Founding Fathers 3-26 (T. Colbourn ed.

88 Id. at 24. 
same professional community, have life tenure, and can climb no higher?

\section{Judicial Review and Legislative Tyranny}

\section{A. Judicial Review as a Constraint}

Tushnet claims, as we have seen, that the "liberal tradition" depends on judicial review to eliminate legislative tyranny. If he were right about that-and Part III will argue that he is not-he would also be right, incontestably right, that this mission is impossible. For one thing, judicial review cannot itself guarantee that the limitations it places on legislators or executives will be respected, court orders obeyed or enforced, court decisions accepted as binding precedents by anyone other than lower-court judges, if indeed by them. In a Hobbesian society, fidelity to the Rule of Law cannot be assumed.

Second, even in a non-Hobbesian world, no theory of judicial review-however little it may constrain the courts, however sweeping a veto power it may give them-can assure that courts will use that power to control legislators. Tushnet writes as though the game of constraints were a zero-sum game; the more we constrain judges, the less we constrain legislators, and vice versa. The blanket pulled to one side of the bed exposes the other. This analysis, however, underestimates the problem. In fact, we could not prevent legislative tyranny even if we cared nothing at all about restraining judges and were content for them to roam at will. A constitutional provision that authorized the Supreme Court to veto any act of Congress within 30 days would give the Court far more nay-saying power than any constitutional theory ever proposed, but would still leave Congress free to do as it pleased unless and until the Court said no. Under such a provision, judicial review would constrain Congress in much the same way the two Houses of Congress constrain one another, neither being able to act without the other's concurrence, and the way the President's veto power constrains both (in the absence of supermajorities). But just as the possibility of legislative tyranny is not ruled out (though it is materially reduced) by the tripartite filtration system of House, Senate, and President, so it would not be ruled out (though it would be further reduced) by adding the Supreme Court as another filter.

It might be argued that the Supreme Court, unlike the political branches, is in a position to render a dispassionate judgment free from majoritarian pressures. That the Court may be sparing in its use of the constitutional veto is suggested by the "sociological" considerations (as 
Tushnet calls them) previously noted: ${ }^{69}$ that judges and legislators are drawn from roughly the same demographic pool, tend to see issues from similar points of view, and rarely reach different conclusions; that judges are not ivory tower philosophers but politicians or civil servants with life tenure, merely another part of the society's governing coalition. Thus the same "realities" that ease the danger of judicial tyranny weaken the effectiveness of courts as guardians against legislative tyranny.

In some ways, moreover, judicial review constrains legislators even less than the two congressional bodies and the presidency constrain one another. A statute need not be approved by a court in advance before going into effect. Courts speak only after the fact-sometimes decades or generations after the fact, as in Brown and Roe-and only when asked. Even then, their mandate is addressed to the executives who enforce the statute rather than the legislators who enacted it, and often nullifies only the particular application or class of applications involved in the case at hand, rather than the statute at large.

\section{B. Legislative Tyranny: A Boundless Concept}

While judicial review cannot eliminate the potential for legislative tyranny, it can reduce it. To what extent it can realistically be expected to do so depends in part on how "legislative tyranny" is defined. An eighteenth century approach adopted, among others, by Madison, Jefferson, Hamilton, and Montesquieu defined tyranny as "the accumulation of all powers legislative, executive, and judiciary in the same hands." "70 Power too heavily concentrated, or too little constrained, was deemed "tyrannical" no matter what was done with it. That structural definition of tyranny could not be applied with a straight face to America's constitutional system at any time in our history, and Tushnet does not adopt it. Instead, he uses the term more or less interchangeably with "oppression," or extreme legislative or judicial misbehavior, and he speaks repeatedly of the "threat" or "potential" or "opportunity" for tyranny, rather than of tyranny as inhering in the constitutional power structure itself. ${ }^{71}$

Beyond these hints, however, Tushnet does not define legislative tyranny. Here again, however, he does give examples. From the perspective of "self-styled conservatives" he offers as instances of possible

69 See supra notes 29-30 and accompanying text.

70 The Federalist, supra note 1 , at No. 47 (J. Madison); see also G. Wills, EXPlainING AMERICA: The Federalist 111-12 (1981).

71 See M. Tushnet, supra note 2 , at 10, 14, 72, 180, 185, 186 
legislative oppression "an out-of-control budget or inadequate spending for defense." 72 In a 1983 article, though in precisely the same context, he gave examples from his own vantage point on the left:

Legislative oppression has taken the form of a tax system skewed substantially against redistribution of wealth, a system of subsidies to political activity that at least perpetuates and perhaps magnifies the disparities of power that are occasioned by disparities in wealth, and a system of public assistance to those in need that is administered by a bureaucracy that degrades its supposed beneficiaries. ${ }^{73}$

What do these examples imply? First, "tyranny" is, for Tushnet, very much in the eye of the beholder: Anything counts that anyone counts. To eliminate the threat of legislative tyranny, constitutional theory would have to rule out all legislative outcomes that any significant group in the society believed to be oppressive.

In many instances, a conscientious legislature devoted to the public interest (like a conscientious court in the parallel judicial situation) will find itself damned if it does and damned if it doesn't. Too much redistribution or too little, too much spending on defense vis-a-vis welfare or vice versa-tyranny for someone lies on either hand. Perhaps an angelic government could find a golden mean in these cases, but in other cases no middle ground would be available even in principle. Banning abortion, or school prayer, or pornographic literature that debases women will be tyranny to some; not banning it will be tyranny to others. Once that is recognized, the inability of constitutional theory to prevent legislative, let alone judicial, tyranny becomes syllogistic. Nor could legislatures escape this dilemma by adhering to the formula, "when in doubt, don't," on the premise that inaction could permit tyranny but never commit it. That premise is unsound if one's conception of rights includes affirmative claims upon the state for protection and assistance. ${ }^{74}$ If, for example, fetuses have an affirmative right to life, so that Roe $v$ Wade, a judicial decision voiding an anti-abortion statute, is tyrannical (on grounds other than its countermajoritarian character), the same should be true of a legislative decision repealing that statute and achieving thereby identical results: no prohibition and the abortion choice in private hands. In other situations, moreover, inaction is not

72 Id. at 28 n.28.

${ }^{33}$ Tushnet, Following the Rules Laid Down: A Critique of Interpretation and Neutral Principles, 96 HARv. L. REv. 781, 788 n.19 (1983).

788 n.19 (1983).

74 See infra text accompanying notes $45-52$. 
even an option: order prayer in or out of the schools, operate racially imbalanced schools or try to balance them through busing, use race as an employment criterion or use nonracial criteria that perpetuate the effects of past discrimination-in these and many other cases, doing nothing is not an available alternative.

Second, tyranny in Tushnet's lexicon appears to include actions far removed from what we usually think of as human rights concerns such as speech, religion, race, privacy, procedural fairness, and the like. Tushnet himself grants that "courts have essentially nothing to say, at least in the language of constitutional law, about the size of the national budget, its distribution between social welfare and military programs, the scope of public regulation of enterprise, or foreign policy."75 Whether Tushnet approves of this muteness is unclear; the great majority of interested observers undoubtedly do.

What may be implicit in Tushnet's examples is the idea that all use of coercive power by government without the consent of the coerced is, in and of itself, tyranny-at least if so regarded by the coerced. With or without that proviso, tyranny, so viewed, would be virtually coextensive with government and a pervasive phenomenon not only in our pluralistic polity, but even in the republican society of Tushnet's aspirations. ${ }^{76}$ At all events, with tyranny defined in such expansive terms, the inability of judicial review to prevent it is about as significant as its inability to cure cancer.

\section{Self-Interest and Tyranny}

A fairer reading of Tushnet's analysis, however, suggests a more limited definition of tyranny: the use of coercion by power-holders acting with a view to their own interest or the interest of a narrow group rather than with a view to the common good. Tushnet's willingness to cast so broad a net in his catalogue of tyrannies may depend on his premise that politics, both in liberal theory and in American reality, is a Hobbesian politics of self-interest. Here, as in the judicial case, Tushnet does not specify exactly what connection he sees between selfinterested motivation on the part of legislators and legislative tyranny, or whether that connection is causal or conceptual. ${ }^{77}$ Nor does he attempt to sharpen and clarify the protean concept of self-interest itself. In earlier writing, Tushnet, describing the behavior of power-holders whose motivations fit the Hobbesian mold, declared that, unless

${ }^{75} \mathrm{M}$. Tushnet, supra note 2, at 169.

${ }^{76}$ See infra text accompanying notes 202-05.

77 See supra text accompanying notes 54-55. 
checked, "they will use their positions to advance their own interests. Either they will coerce others in order to enhance their own income-in cash, respectability, the rush one gets from exercise of power, or otherwise-or they will coerce them paternalistically."78 Once selfinterest is stretched to include respectability, the pleasures of using power (even, presumably, in the public interest), and paternalism, its linkage to tyranny becomes highly problematic.

Self-interest in the hard-boiled Hobbesian sense of insatiable pursuit of money and power is readily incorporated into the definition of tyranny, but not so readily imputed to most federal judges or even most federal legislators. Conversely, soft-boiled self-interest-concern for reputation or respectability, the satisfactions of benevolence and paternalism-is ubiquitous but not blameworthy, let alone tyrannical. It is only by shifting from a hard-boiled to a soft-boiled definition as one moves from the conceptual to the empirical plane that the gap is bridged.

\section{An Alternative Test of Tyranny: Worst and Best Outcomes}

At one point in Red, White, and Blue, Tushnet proposes a somewhat more specific standard for evaluating constitutional theories. $\mathrm{He}$ invites the reader to determine the best and worst politically feasible outcomes she can imagine in the next ten years and suggests that a constitutional theory is indefensible if it would allow judges to uphold the latter and invalidate the former. ${ }^{79}$ Superficially, this seems fair enough, until one reflects, in light of the previous discussion, on what sort of candidates are likely to be proposed for worst and best "politically feasible" outcomes. Observers on the far left might nominate, as the worst feasible prospect, a perpetuation of the Reagan Revolution, the further dismantling of social programs, or the deployment of the Strategic Defense Initiative-all outcomes that would be untouchable by the courts under almost any constitutional theory ever seriously proposed; and as the best potentially feasible result, racial quotas in employment or education unrelated to past discrimination, a measure that would be held invalid under present doctrine; or, less realistically, the large-scale redistribution of existing real property holdings without full compensation to the owners, a measure sure to be voided under any reading of the "just compensation" clauses. For those on the far right, the corresponding "worst" and "best" selections might be, respectively,

78 Tushnet, Anti-Formalism in Recent Constitutional Theory, 83 MicH. L. REv. 1502, 1505 (1985).

79 See M. TushnET, supra note 2, at 186. 
a major increase in the personal or corporate income tax (clearly constitutional), and the enactment of the death penalty for first-offending drug dealers (quite possibly unconstitutional). These outcomes seem a long way from rendering "indefensible" the constitutional theories that permit them.

Furthermore, the results of the "worst politically feasible outcome" test would depend, with perverse consequences, upon the society's past record in the field of civil rights and social justice. The gentler, the kinder, the more tolerant a society has been in the past, the more likely it is that its worst foreseeable behavior in the future will pass muster under any given constitutional theory and thereby discredit that theory under Tushnet's criterion. Conversely, the more nearly a society resembles a police state, the greater the likelihood that its foreseeable worst will exceed consitutional limits under any given theory, thus vindicating that theory in Tushnet's eyes.

\section{E. Constitutional Theory and Comparative Pragmatism}

Tushnet does not always argue that the success of a constitutional theory should be measured in all-or-nothing terms, that is, by whether it completely eliminates the threat of tyranny. He writes that "the fundamental issue for any theory of judicial review is a comparative one: will the judicial enforcement of the limitations the theory proposes to place on legislative action yield 'better' results than judicial enforcement of some other limitations or no judicially enforced limitations at all?"80 And he appears to concede the legitimacy and even the power of "pragmatic" arguments that justify a constitutional theory on the ground that in light of its actual or predicted political consequences it provides the best available mix of constraints on judges and legislators. ${ }^{81}$

From the standpoint of the liberal tradition (in Tushnet's version of it), this task appears to be a secondary mission for constitutional theory: Unable to provide the full measure of restraint that liberalism requires, constitutional theory should point the way to the least tyrannical alternative. This role for the theoretical enterprise, the search for second-best, or least costly solutions, is similar to that performed by applied theory in other fields.

In principle, Tushnet is clearly right that no constitutional theory is complete without some consideration of its likely practical consequences in comparison to those of rival theories. A full-fledged comparative analysis would, however, be a labor worthy of Hercules. It would

81 See id. at 27-32, 71-72, 123-33. 
not be enough simply to compare worst-case-scenarios, or even worstprobable-case scenarios. One would have to make comparative predictions as to how legislatures, state and federal, are likely to act in the future under alternative constitutional theories and what use the Supreme Court is likely to make of whatever discretion various constitutional theories allow it. The normative judgments would be even more difficult, depending heavily on the appraiser's own political, moral, and jurisprudential values. Observers from the left and right, respectively, might agree fully in their assessments of future events yet, for that very reason, reach diametrically opposite conclusions as to the comparative practical merits of alternative theories.

Nor would these be the only problems. A theory that won hands down in the tyranny-prevention sweepstake might still deserve to be rejected if it paralyzed the government. ${ }^{82}$ The system of checks and balances and separation of powers that Tushnet finds so inadequate in meeting the liberal tradition's demands for constraint against tyranny is vigorously criticized by many political scientists for providing all too much constraint and for having produced a century of deadlock and divided government. Indeed, in any general cost-benefit comparison of constitutional theories, it is questionable whether the obscure, ill-defined, and highly subjective concept of tyranny would have any useful place at all. It is difficult enough to weigh interests in life, liberty, property, dignity, fairness, and happiness, without having to filter them through the cloudy lens of "tyranny."

Although Tushnet does not undertake a full-fledged comparative analysis of grand constitutional theories, he does evaluate, in a noncomparative and admittedly tentative way, the pragmatic arguments for each. He rejects the pragmatic case for representation-reinforcement ${ }^{83}$ and finds the arguments for the other two inconclusive. ${ }^{84}$ Given that the test is "comparative," that the race is not necessarily to the swift but to the least unswift, it may seem odd that Tushnet is unwilling to declare any of the competitors a winner. Perhaps he thinks all three theories provide so little constraint that it is not worth quibbling about which gives most. Undoubtedly, his negativism also reflects his legal realistic sense that constitutional decisions of the Supreme Court do not make much difference in our society. This last point, which we have already

82 See J.M. Burns, The Deadlock of Democracy: Four-Party Politics in America 6-23 (1963); J. Sundquist, Constitutional Reform and Effective Government 8-12, 75-78 (1986); Cutler, Party Government Under the American Constitution, 134 U. PA. L. Rev. 25 (1985) (noting the frequency and arguing the demerits of divided government vis-a-vis party government).

${ }^{83}$ See M. Tushnet, supra note 2 , at 72 .

see id. at 32, 133. 
encountered in other contexts, ${ }^{85}$ is worth separate discussion.

\section{F. The "Sociological" Factor}

At the very outset of Red, White, and Blue, Tushnet announces that the book has "two basic themes," one logical, the other sociological. ${ }^{86}$ Readers of this essay have encountered both. The logical theme is that liberalism makes judicial review and constitutional theory both necessary and impossible. The sociological theme, drawing heavily on the insights of modern social and political science and on the jurisprudential tradition of Legal Realism, emphasizes that "over the medium to long run, courts are part of a society's governing coalition;"87 that judges and legislators are demographic cousins; ${ }^{88}$ and that controversial Supreme Court decisions will often not be fully implemented ${ }^{89}$ and will make a difference only when contemporary majorities or near-majorities want them to. ${ }^{90}$ For example, he says, abortion was on the increase even before Roe; and that decision "may have only accelerated slightly the trend toward legalizing abortions not the trend toward having them."91 Police practices were being reformed even before Miranda $v$. Arizona. ${ }^{22}$ The political process, not the Court, played the leading role in civil rights during the 1960 s, and race relations today may be no different than if blacks had been forced to rely on politics alone. ${ }^{93}$ Even in the first amendment area, decisions of the Supreme Court deemed "extreme" by the great majority of the public may fuel resentment and actually "entrench" the legislators' deeply ingrained "urge to repress,"94 so that the net benefit to free speech may be small.

The sociological argument thus has ambivalent implications for Tushnet's impossibility theorem. On one hand, it severely undercuts the proposition that judges are likely to behave like tyrants unless tightly constrained and that constitutional theory is therefore a necessary check against judicial tyranny. On the other hand, it reinforces the proposition that judicial review is a weak reed against legislative tyranny. It does so, however, for a reason quite different from the one assigned by the logical theme: Judges cannot be depended on for aggressive counter-

8s See supra notes $28-29,68$ and accompanying text.

${ }^{86} \mathrm{M}$. TUSHNET, supra 2 , at viii.

87 Id.

${ }^{88}$ See id. at $197-98$.

89 See id. at 198.

80 See id. at $120,184$.

81 Id. at 131.

92384 U.S. 436 (1966); see M. TUSHNET, supra note 2, at 132.

${ }^{23}$ See M. Tushnet, supra note 2, at 132.

94 Id. at 127-28. 
majoritarian action, not because constitutional theory disables them, but because their own backgrounds and perspectives disincline them.

Both Tushnet's themes, the logical and the sociological, contain hard-boiled, and somewhat unflattering, hypotheses about judicial motivation and behavior. Superficially, these hypotheses appear to be at odds with one another. The logical, or liberal, theme sees judges as Hobbesian self-aggrandizers apt to abuse their countermajoritarian power unless reined in by constitutional theory. The sociological, or Legal Realist, theme sees judges not as countermajoritarian wolves, but as majoritarian sheep, prone to rubber stamp legislative decisions except where the constitutional text or precedent leaves them no choice but to act. In terms of the sociological theme, one could argue that the needed role for constitutional theory is to activate, not de-activate, the courts; to serve as an engine, not a brake; a source of Thou-Shalt's rather than of Thou-Shalt-Not's.

It may well be this contrast between the Hobbesian and Legal Realist visions of judicial "nature" is overdrawn. A Hobbesian judge might well find that her own interest, or that of the economic or social class with which she identifies, or that of the court of which she is a member, is more often served by approving majoritarian decisions than by countering them. The Legal Realist insight that judges are creatures of flesh and blood, passion and interest, rather than disembodied oracles, and the sociological analysis of where their passions and interests are likely to lead them, may simply be elaborations of the basic Hobbesian premise.

The converse may also be true. Just as the Hobbesian premise does not necessarily imply judicial activism, the insights of sociology do not ineluctably lead to judicial quiescence. First, the demographic congruence between judges and legislators does not automatically translate into ideological congruence. The three majoritarian institutions of the federal government-House, Senate, and Presidency-are at least as similar to one another demographically as any of them is to the Supreme Court, yet they often have quite different partisan or ideological complexions. Even on the assumption that the members of the Supreme Court originally shared, and continue to share, the political values of the Presidents who appointed them, there is no guarantee they will share the values of the legislators, past or present, who enacted the particular statutes under scrutiny.

Second, even assuming a high degree of similarity, both demographic and ideological, between judges and legislators at the national level, there is undoubtedly much less of both when the comparison instead is between national judges and state or local legislators or officers; 
that may be one reason, among others, why the Supreme Court much more often invalidates state action than federal action.

Third, the assumption that the Supreme Court is a quasimajoritarian institution, "part of a society's governing coalition," dos does not necessarily imply self-subordination to other institutions. On the contrary, other power-wielding components of our government-Congress and the Presidency, the executive bureaucracies, the military services - often battle one another fiercely for power and turf. If the Supreme Court exhibits greater deference-for example, in the area of economic regulation-the reason is not that the Court sees itself as a third legislative chamber, but precisely that it does not.

These general observations suggest the possibility-I will put it no more strongly - that even on the premises of Legal Realism, judicial review, though certainly no sure bulwark against legislative tyranny, may have greater impact than Tushnet allows. Historically, this seems to me to have been the case. Tushnet's contention that Supreme Court decisions on abortion, race, speech, and criminal justice have left those areas pretty much as they would have been without the Court's intervention-though a useful deflator of exaggerated claims of importance for those decisions-is itself a not inconsiderable exaggeration.

That Brown v. Board of Education ${ }^{98}$ was not immediately implemented in the area of school segregation itself cannot obscure its importance in galvanizing the energies of the civil rights movement, in focusing public attention on racial issues, and in providing a catalyst for the congressional action of the following decade. ${ }^{97}$ Moreover, the later busing decisions, ${ }^{98}$ despite the softening of their impact by demographic developments and by the departure of many whites from urban public school systems, ordered changes that scarcely any legislative body at any level of government was (or is) prepared to order on its own. As for the first amendment, it is hard to believe that freedom of expression would be nearly as well-protected today in the absence of judicial review, or if the Court had persevered in the hands-off position it originally took in cases such as Abrams v. United States ${ }^{99}$ and Gitlow v. New York. ${ }^{100}$ And the suggestion that Supreme Court decisions popularly perceived to be overprotective may have provoked an equal and

9s $I d$. at viii.

96347 U.S. 483 (1954)

97 See, e.g., R. Kluger, Simple Justice 748-61 (1986).

${ }^{98}$ See, e.g., Keyes v. School Dist. No. 1, Denver, Colo, 413 U.S. 189 (1973);

Swann v. Charlotte-Mecklenberg Bd. of Educ., 402 U.S. 1 (1971).

92250 U.S. 616 (1919).

100268 U.S. 652 (1925) 
opposite legislative backlash seems to me simply false. ${ }^{101}$ In the area of criminal justice, Tushnet's speculation that police administrators would have reformed the abuses that concerned the Warren Court even without benefit of the Court's decisions is unconvincing. Some might have, others assuredly would not. It is almost unimaginable that police reformers, prosecutors, or legislatures would voluntarily have adopted safeguards comparable to those the Warren Court constructed in decisions such as Miranda, ${ }^{102}$ Mapp v. Ohio, ${ }^{103}$ and Gideon v. Wainwright. ${ }^{104}$ These sketchy, and insufficiently documented, assessments are meant to be merely suggestive. Fuller exposition and more precise judgments would require extensive research. My purpose is simply to call into question Tushnet's view that Supreme Court decisions do not matter. There is an alternative hypothesis, equally consistent with the spirit of Legal Realism and perhaps more consistent with the historical record: The "sociological" factors outlined by Tushnet may give adequate assurance that judges will not be tyrants while still leaving them

101 The recent presidential election may have featured a backlash by voters against the American Civil Liberties Union for having taken positions (especially in the area of child pornography) widely perceived to be extreme. Candidates (if any) elected as a result of that backlash may in future cast legislative votes in support of repressive legislation. This highly speculative scenario, however, falls far short of justifying Tushnet's conclusion that free speech has gained little from court decisions. The Supreme Court's recent, highly unpopular decision in Texas v. Johnson, $109 \mathrm{~S}$. Ct. 2533 (1989) - invalidating a state flag-desecration statute on first amendment grounds-may well result in a constitutional amendment aimed at overruling that decision. But in order to exemplify Tushnet's backlash theory, the majoritarian response to an unpalatable Supreme Court decision must go beyond the negation of the triggering decision itself; that alone would merely leave the first amendment where it stood on the eve of the Court's action. Only if the immediate backlash (generated by a case such as Johnson) pares the way for additional incursions on the first amendment in the future will it have produced a net loss for freedom of expression and thus a partial offset to the speech-protective effects of other Supreme Court decisions. Tushnet cites no examples of such net-repressive backlashes. Meanwhile, the haste with which members of Congress have rushed to condemn Johnson makes it hard to share Tushnet's judgment that our representative institutions would take good care of the first amendment in the absence of judicial review.

${ }_{102}$ Miranda, 384 U.S. 436 (1966).

103367 U.S. 643 (1961). To be sure, most police administrators have learned to live with these decisions, especially Miranda, and today seek only marginal modifications even of the exclusionary rule. And even if it were true that the Court merely helped progressive police administrators get where they really wanted to go, that facilitation alone might have been indispensable to the result.

104372 U.S. 335 (1963). Gideon and its progeny brought about an extraordinary change in the right to counsel, requiring the appointment of lawyers for small felony and misdemeanor cases both at trial and on appeal. The states, which up to that time had done little to establish effective public defender systems, were now required to do so and to fund them at a level that would assure effective assistance of counsel. The fact that there are still substantial inadequacies in defender systems does not detract from the fact that, in most states at least, they are far better today than they ever were likely to have become without the Court's intervention. 
with sufficient independence from political pressures to be able to curb truly egregious legislative excesses and to collaborate effectively with legislators in an interactive process that achieves reforms neither institution could achieve alone. If this hypothesis is valid, judicial review would still not satisfy the heroic counter-tyranny demands made upon it by Tushnet's "liberal tradition," but it would certainly be justifying its existence as a constructive part of our system of checks and balances.

\section{Judicial Review and the Liberal Tradition}

\section{A. Introductory}

The manifest unreasonableness of expecting judicial review to eliminate completely the risk of legislative tyranny as conventionally defined, or to address at all certain forms of legislative tyranny singled out by Tushnet in his idiosyncratic definition, makes it important to examine the supposed historical sources of this impossible mandate. Tushnet repeatedly states that it is the "liberal tradition" that "demands" or "requires" that judges constrain legislators. He presents the liberal tradition and its rival, the civic republican tradition, as "two general theories of citizenship" that "contended on roughly equal terms" during the era in which the Constitution was formed. ${ }^{105}$

The liberal tradition, epitomized in the philosophy of Thomas Hobbes, considered people to be motivated, in large measure, by "possessive individualism," the desire to maximize their material well-being. The civic republican tradition emphasized instead the "essential social nature of individual being"; it saw people as "social beings who draw their understandings of themselves and the meaning of their lives from their participation with others in the social world that they actively and jointly create." ${ }^{106}$ Tushnet is careful to note that the traditions "are distinguished largely by matters of emphasis," that "few people adopt one or the other ... in its entirety," and that "systematic thinkers often develop creative syntheses of elements in both traditions." 107 Thus, while the republican tradition was "less suspicious of

105 M. Tushnet, supra note 2 , at 4.

${ }^{108} I d$. at $5,10$.

107 Id. at 5, 7. These cautious shadings are entirely appropriate but hard to reconcile with the stark contrast implicit in Tushnet's ultimate conclusion that whereas liberalism makes judicial review necessary but impossible, a revived republicanism would make it possible but unnecessary. See id. at 317 . The difference between the two characterizations of the liberal-republican relationship can perhaps be explained on the ground that Tushnet's vision of a twenty-first century civic republic is intended not merely to recapture the republican tradition of old, with all its grayness and complexity, but to extract its pure essence, the concept of civic virtue in a radically decentralized 
government" than the liberal tradition, it "did not romanticize human nature" and understood that people will sometimes "heed the call of self-interest rather than that of public interest."108 And although republicans, "consistent with their traditionalism could have been inattentive to questions of institutional design" (in contrast to liberals, who needed well-designed institutions in order to constrain the self-interested exercise of official power), eighteenth century republicans were in fact "deeply concerned about institutions" because of their intense fear of what they called corruption, the use of public offices for private interest, and their conviction that properly designed institutions could constrain corruption and instill civic virtue, "reinforcing the citizenry's dedication to the public interest." 108 The two traditions, moreover, converged in supporting, albeit for different reasons, the institutions of private property, federalism, and judicial review that came to be embodied in the Gonstitution. In Tushnet's analysis, liberalism required judicial review as a constraint against the abuse of power by pervasively selfinterested legislators, republicanism as a safeguard against occasional legislative corruption. Civic republicanism thus made more modest demands upon the institution than did liberalism and, Tushnet indicates, it was this modest conception that the framers embraced. ${ }^{110}$

Tushnet is right in cautioning that the two traditions have vague contours and that the differences between them are ones of emphasis. Even that caveat, however, may not suffice: Any attempt to frame a dichotomy between republicanism and liberalism in the eighteenth century inevitably involves an element of reification. The core ideas of the two-positive liberty (political participation) and civic virtue on the one hand, negative liberty and the economic virtues on the other-were entirely compatible, even complementary, and comfortably coexisted in the minds of many eighteenth century political thinkers. ${ }^{111}$ Both were

polity.

${ }^{108} \mathrm{Id}$. at $6,11$.

109 Id. at $10-11$.

110 See id. at 12-13, 15.

121 Of the handful of political writers often considered the leading voices of the radical Whig tradition of opposition and protest; the tradition of the "county party" and of civic values - in short, of the republican tradition-in eighteenth century Britain-John Trenchard, Thomas Gordon, Henry St. John (Viscount Bolingbroke), James Burgh, Joseph Priestley, and Richard Price-all but one, Bolingbroke, were in important respects Lockean liberals as well.

Trenchard's and Gordon's weekly series of letters under the pseudonym "Cato," see supra note 65 , were not only among the most significant political writings of the Augustan period but also "the most popular, quotable, esteemed source of political ideas" for the American colonials on the eve of revolution. See C. Rossiter, SEEDTIME of the Republic: The Origin of the American Tradition of Political LibERTY 141 (1953); see also D. LUTZ, The ORIGINS of AMERICAN Constitutional- 
part of a larger body of thought described by one historian as "the Whig science of politics,"112 a tradition that defined itself in opposition to a series of changing power structures in the century before the American revolution. By the time of that conflict, the two intellectual streams, despite their different origins, had long since flowed together and were probably no longer clearly distinguishable in the minds of most political thinkers.

I shall argue that the liberal tradition, as embodied in the writings

ISM 143 (1988). In their fierce denunciation of corruption, privilege, the rise of monied power and its destabilizing effects on constitutional balance, credit, luxury, and the absence of public spirit, Cato's Letters epitomized the country ideology and set a polemical standard that even Bolingbroke, writing in the next decade, was hard pressed to match. Yet in their concern for individual rights of liberty and property, their conviction that the business of government is to protect those rights and their contractarian account of the origins and limits of the state, they were every inch Lockean liberals.

A similar medley of liberal and civic themes can be found a half-century later in the reformist writings of Price, Priestley, and Burgh. All three published important political works on the eve of the American revolution, took the side of the colonies in their controversy with the mother country, and were, in turn, widely read and admired in this country. Historians have found them hard to classify. Their withering opposition to standing armies, corruption, and privilege in all its long-familiar forms mark them, for some historians, as perpetuators of the country tradition. See Fruchtman, The Apocalyptic Politics of Richard Price and Joseph Priestley: A Study in Late Eighteenth Century Republican Millenarianism, in 73 Transactions of the American Philosophical Society 1, 67-80 (1983); see also L. Banning, The JefFersonian PerSUASION 60-62 (1978); C. RobBins, The Eighteenth Century ComMONwEALTHMAN 335-53, 364-68 (1959). Other historians, disagreeing, see them instead as middle-class reformers, mainly by virtue of their advocacy of the franchise for the landless but monied bourgeoisie. See Kramnick, Republican Revisionism Revisited, 87 AM. HIST. REv. 629, 640-41 (1982). What is clear, especially in the case of Priestley and Price, is the heavy debt they owed to Locke as the source of their basic ideas on liberty and the state.

Priestley's Essay on the First Principles of Government, published in 1771, was "virtually a gloss on [Locke]." Kramnick, supra, at 646. And Price's Observations on the Nature of Civil Liberty, appearing in 1776, begins with an acknowledgement that "the principles on which I have argued form the foundation of every state so far as it is free; and are the same as those taught by Mr. Locke." Price, Observations on the Nature of Civil Liberty, the Principles of Government, and the Justice and Policy of the War with America, in Richard Price and the Ethical Foundations of THE American Revolution 65 (B. Peach ed. 1979).

Both Pricstly and Price distinguished between, and assigned equal importance to, two concepts of liberty: political liberty as affirmative right of participation in selfgovernment, a concept dear to the republican tradition; and liberty as a negative, prepolitical right of the sort traditionally associated with liberalism. Both writers regarded the former, among other things, as a means to effective protection of the latter. In the case of Burgh, whose three-volume Political Disquisitions, published in 1774 and 1775 , was a thorough and scholarly treatment of contemporary reform issues, the Lockean element was less prominent but still significant, especially in his attack on parliamentary malapportionment, the unrepresentative character of the House of Commons, and the effective disenfranchisement of a large part of the British citizenry. See J. Burgh, Political Disquisitions (1971). (1972).

${ }_{12}$ G. Wood, The Creation of the American Republic, 1776-1787, at 3-45 
of its best known exemplars, theorists such as Hobbes, Locke, and Bentham, was silent about judicial review (except for Bentham's rejection of it) and contributed only marginally to the development of the more general concept of institutional checks and balances. Moreover, the Hobbesian vision of passionately selfish human nature was widely held even by non-liberals, was considerably moderated by some liberals, and (in anything like its strong form) was not embraced by the framers. Finally, the framers, whatever sources they may have drawn upon, did not contemplate for judicial review the central role in tyranny-prevention that Tushnet says the liberal tradition required.

These conclusions do not directly contradict any specific claim advanced in Red, White, and Blue for two reasons. First, Tushnet does not equate the "liberal tradition" with the writings of systematic political theorists such as Locke or Bentham. He acknowledges that most such thinkers "have had a more subtle understanding of the problems than those I will describe as inherent in the tradition." 113 Instead, he locates the tradition in a genre he calls, without further explanation, "amateur political theory." 114 In another passage he defines the "liberal tradition" to be "liberalism as lived and experienced in the culture rather than the systematic thought of particular thinkers." 116 These disclaimers, however, do not make irrelevant the conclusion that judicial review had no place, let alone a place of critical importance, in liberal political theory of the formal sort. The fact that careful thinkers such as Locke and Bentham did not infer from their individualistic premises the necessity for a judicial safety net lessens the plausibility of Tushnet's bald assertion that unnamed amateur political theorists or, even more nebulously, American political culture, did draw that inference or were logically obliged to do so. It underscores the need for proof on this issue and the conspicuous absence of it in Tushnet's analysis.

Second, Tushnet does not claim that the framers derived their conception of judicial review from premises supplied by the liberal tradition, no matter how defined. On the contrary, his contention seems to be that it was civic republican assumptions that shaped the framers' expectations of this institution. The framers believed they were designing institutions for "a republic dominated by civic virtue," a world "in which civic virtue reigned."116 Their answer to the liberal's quandary as to why judges, in policing self-regarding legislators, would not themselves be purely self-regarding, was that "judges, like others in the na-

113 M. TUSHNET, supra note 2, at 5 n.9.

114 Id.

115 Id. at 13 n. 35 .

${ }^{116} I d$. at $40,41$. 
tional government, would 'discern the true interest of their country' because they were selected from a nation-wide pool and were given guarantees of tenure that assured that they would interpret the constitution responsibly." ${ }^{117}$ The framers, moreover, drawing on the republican tradition, believed that the Constitution had a "plain meaning." Thus, civically virtuous judges would enforce the terms of a readily understood constitution in the occasional instances in which a generally public-spirited national legislature crossed the constitutional line. These assumptions, as it turned out, were "eventually invalidated"118 (says Tushnet) by the framers' commitment to private property, the politicization of judicial appointments, and other developments.

I shall argue that Tushnet is right in suggesting that the framers, insofar as they theorized at all about the role of judicial review in the constitutional scheme, had rather modest expectations for it, but that he goes too far in suggesting that the framers believed the Constitution had a "plain meaning" and would virtually interpret itself. ${ }^{110}$ The latter point is important for the following reason: The false notion that the framers' "republican" vision of judicial review included a simplistic "plain meaning" theory of constitutional interpretation lends undeserved plausibility to Tushnet's further claim that this vision was "invalidated" by later events, thereby making constitutional theory both necessary and impossible. Once it is recognized that the framers held no such unrealistic theory of constitutional interpretation, that they had no illusions about the necessity for difficult and controversial calls in interpreting the Constitution, it becomes far less clear that their vision of a public-spirited federal judiciary grappling with constitutional issues in a responsible way was invalidated by subsequent developments.

\section{B. Judicial Review: Not a Liberal Idea}

Judicial review was not an idea inherited by the framers from political theorists, liberal or otherwise. Neither Hobbes nor Locke, liberalism's founding fathers, had any conception of it. Indeed, Hobbes had no interest in institutional design of any kind; fearing anarchy more than tyranny, he assigned all and undivided power to an absolute sovereign and left it at that. Locke, for his part, theorized about natural rights and limited government but did not contemplate that judges would enforce those rights and limitations against legislators. Like other seventeenth century writers, he envisioned a two-fold division and

${ }^{117}$ Id. at 15 (quoting The Federalist, supra note 1, at No. 10 (J. Madison)).

118 M. TUSHNET, supra note 2 , at 15.

11 See id. at 12-13. 
separation of powers: executive and legislative. ${ }^{120}$ Should either exceed its authority and violate its trust to the people, they had "no Judge on Earth" but only an "appeal to Heaven"-that is to say, an appeal to arms. ${ }^{121}$ By the middle of the next century, major figures in the republican, not the liberal, tradition, such as Bolingbroke in England and Montesquieu in France, had added the judicial to what now became a triad of powers, ${ }^{122}$ but even they did not suggest that judges should be able to disregard statutes. Nor, apparently, did any other eighteenth century political philosopher.

The writers just mentioned never considered the idea of judicial review one way or another. Jeremy Bentham, a third liberal progenitor, did consider the idea and thought it a bad one: "Give to the Judges a power of annulling [Parliamentary] acts," he wrote, "and you transfer a portion of the supreme power from an assembly which the people have had some share, at least, in choosing, to a set of men in the choice of whom they have not the least imaginable share."123 In the half century that followed, Bentham further developed the constitutional implications of the utilitarian ethic. Like Hobbes, he believed that human behavior was driven by self-interest, that governors would care for the public good only to the extent it corresponded with their own, and that institutions must be designed so as to bring about this correspondence. Yet he never changed his mind about judicial review; for to circumscribe legislative direction in accordance with rules previously laid down would in Bentham's view, work against the "greatest happiness" principle. ${ }^{124}$ Instead, he relied on the ballot box to keep the interests of the governors in line with those of the governed.

The framers, to be sure, "did not pluck the concept of judicial review from the void." 125 They found support for it in the British common law tradition, mainly in Sir Edward Coke's famous dictum in Bonham's Case nearly two centuries earlier that "when an Act of Parliament is against common right and reason ... the common law will control it and adjudge such an act to be void."126 This now discredited

120 See M.J.C. Vile, Constitutionalism and the Separation of Powers 61 (1967). Locke subdivided the executive power into two parts: executive and federative, corresponding to what we would now call domestic and foreign relations. See J. Locke, supra note 43 , at II, $\$ 147$, at $411-12$.

121 See J. Locke, supra note $38, \S 168$ at 426.

122 See M.J.C. VILE, supra note 120 , at $73,79$.

123 J. Bentham, A Fragment on Government 100 (J.H. Burns \& H.L.A. Hart eds. 1988).

124 See E. Halevy, The Growth of Philosophic Radicalism 407-08 (1966).

${ }^{125}$ R. Berger, Congress and the Supreme Court 23 (1969).

12677 Eng. Rep. 647, 652 (C.P. 1610) 
statement, along with Blackstone's statement disputing it, ${ }^{127}$ were wellknown to the framers. They may have also found suggestive the writings of certain continental legal treatise writers, such as Pufendorf and Vattel, whose view that constitutions are legally, not merely morally, binding on legislators ${ }^{128}$ stopped only a step short of holding that constitutional limitations are judicially enforceable. These legalists were in the natural law tradition and might, by a stretch, be considered "liberals." But they -were in no sense "possessive individualists" in the Hobbesian vein. ${ }^{129}$

\section{G. Checks and Balances: Not Primarily a Liberal Idea}

If liberalism did not contribute the idea of judicial review itself, neither can it be credited with the more general concept of checks and balances, of which judicial review is an instance. The principle that the best structure of government is one in which power is diffused among a number of separate decision-making units, each restraining the others, has been the core concept of western constitutionalism since antiquity. ${ }^{130}$ Moreover, it was a cardinal tenet of the republican political tradition from its inception, ranking in that regard with the concept of civic virtue itself. Contrary to Tushnet's suggestion that republicans "consistent with their traditionalism, could have been inattentive to questions of institutional design,"131 the fact is that "questions of institutional design," mainly having to do with constitutional checks and balances, were at all times a central pre-occupation of republican thinkers. They had no such centrality in the liberal tradition.

The story is too long and complicated to be told here in full, but a brief summary may be useful. ${ }^{132}$ In classical political theory, the ideal

127 See 1 W. Blackstone, Commentaries *91.

128 See Grey, Origins of the Unwritten Constitution: Fundamental Law in American Revolutionary Thought, 30 STAN. L. REv.843, 860-83 (1978). Vattel's statement that "legislators derive their power " from the Constitution and cannot "change it without destroying their authority," VATTEL, The LAW of NATIONS 18 (1760), was apparently well-known to Americans both before and after the Revolution. See Fenwick, The Authority of Vattel, 7 AM. Pol. Scr. REv. 395 (1913); see also R. BERGER, supra note 125, at 27; E. Corwin, The Doctrine of Judicial Review: Its Legal and Historical Basis, AND OTHER ESSays 20 (1963).

${ }_{129}$ Pufendorf, indeed, explicitly rejected Hobbes' radical individualism in favor of a more balanced conception of human nature somewhat more reminiscent of Locke's. See S. Pufendorf, On the Law of Nature and Nations 54, 154-72, 949 (1934).

${ }_{130}$ See M.J.C. VILE, supra note 120.

131 M. TUSHNET, supra note 2 , at 10 .

132 For the full story, see L. BANNING, supra note 111, at 21-69 (1978); Z. Fink, The Classical Republicans: An Essay in the Recovery of a Pattern of Thought in Seventeenth-Century England 1-27, 52-68, 95-120, 153-58, $162-$ 69, 170-92 (1962); K. von Fritz, The Theory of the Mixed Constitution in 
state was conceived to be a mixture of three elementary forms: monarchy, aristocracy, and democracy. Each form alone, it was thought, would in time degenerate into its own particular corruption-monarchy into tyranny, aristocracy into oligarchy, democracy into anarchy. In combination, however, they would withstand this degenerative process, checking one another's excesses, preserving and complementing one another's virtues, imparting necessary stability. The classical theory of "mixed government," as it was called, was taken over by the civic humanists of the renaissance. Machiavelli, for example, wrote that a government combining principality, aristocracy, and democracy would be "stronger and more stable" than a unitary government, since "each would keep watch over the other." 133

In the constitutional controversies of seventeenth century Britain, all parties agreed on one key proposition: that Britain's matchless constitution was a mixed and balanced government on classical lines, with crown, lords, and commons corresponding to the ancient triad of the one, the few, and the many. This proposition, first explicitly advanced in 1642 by Charles I himself, ${ }^{134}$ in response to what he considered the excessive demands of parliament, was embraced by his parliamentary adversaries $^{135}$ and later by the Whigs who opposed the accession of James II and eventually secured his abdication. ${ }^{136}$

For much of the eighteenth century, constitutional controversy centered on the perceived threat to the independence of parliament from efforts of the king's ministers, Robert Walpole and his successors, to corrupt its members by means of pensions, patronage, and other privileges and thereby to secure their support for standing armies, national debt, and other policies favorable to the rising "moneyed interests."137 Both sides-the "country party," as Walpole's opponents were called, and the "court party," Walpole's own partisans-invoked the tradi-

Anriquity 60-95 (1954); I. Kramick, Bolingbroke and His Circle 25, 34, 77 79, 137-52, 250-60 (1968); J.G.A. Pocock, The Machiavellian Moment: Florentine Political Thought and the Atlantic Republican Tradition 189-90, 361-74, 383-85, 401-505 (1975); The Political Works of James Harrington 19-23 (J.G.A. Pocock ed. 1972); C. RoBBINS, supra note 111, at 32-47, 88-133 (1959); Two English Republican Tracts (C. Robbins ed. 1969); C. Weston, English Constitutional Theory and THE House of LORdS 1556-1832, 9-178 (1965); Pocock, Virtue $\mathcal{E}$ Commerce in the Eighteenth Century, $3 \mathrm{~J}$. INTERDISCIPLINARY HIST. 119-134 (1972).

${ }_{133}$ N. Machiavelli, The Discourses, bk 1, ch. 3, at 109 (B. Grick ed. 1970).

134 See J.G.A. POCOCK, supra note 132, at 361-64; C. WESTON, supra note 132, at $23-29$.

135 See C. WESTON, supra note 132, at 30-43.

${ }^{136}$ See id. at 91-123.

137 See I. KRAMNick, supra note 132, at 39-55. 
tional concept of constitutional balance in support of their positions. ${ }^{138}$

Against this background, in the realm of political theory, a succession of opposition writers espoused the principle of mixed and balanced government, a principle many of them thought endangered by the Stuart monarchy in the seventeenth century and by the corrupting encroachments of the executive in the eighteenth. These writers-variously known as commonwealthmen, "true" or "honest" Whigs, or "country" theorists-have been identified by modern historians as the bearers of the civic republican tradition in Britain, a tradition they inherited from classical thinkers and from Machiavelli and passed on to the Americans of the revolutionary period. ${ }^{139}$ The names-James Harrington, Henry Neville, and Algernon Sidney in the seventeenth century; Walter Moyle, Charles Davenant, John Trenchard, and Thomas Gordon (co-authors of Cato's Letters), and, most importantly, Henry St. John (Viscount Bolingbroke) in the first half of the eighteenth; and James Burgh, Joseph Priestley, and Richard Price in the latter years of the century-are not well known today. All but the last three were members of or spokesmen for the landed gentry. Most of them bitterly condemned the rise of the monied interest and its attendant political and moral consequences: luxury, avarice, standing armies, public debt, heavy taxes (particularly on land), corruption in high places, parliamentary subservience. Generally (again with the important exceptions of Burgh, Priestley, and Price), they opposed extension of the franchise to men of money but without land. They glorified civic virtue and constitutional balance-the former as a means of preserving the latter, the latter as a means of preserving the former, and both as a means of preserving individual liberty and happiness. They denounced corruption as the very process by which constitutional balance was destroyed and power increasingly concentrated in the executive. To suggest, therefore, as Tushnet does, that the republican tradition was (and, if revived, might again be) relatively indifferent to constitutional checks and balances disregards a good deal of history.

The relationship between the liberal tradition and the theory of checks and balances is less clear. For Hobbes, any limitation upon the sovereign was a contradiction in terms. Locke contributed importantly to the concept that executive and legislative powers should be separated

138 See C. WeSton, supra note 132 , at 142-78; I. KRAMNICK, supra note 132, at 124-27, 137-52.

139 See L. BANnING, supra note 111, at 42-69; I. KRAMNICK, supra note 132 , at 74, 137-69; 236-60; J.G.A. Pocock, supra note 132, at 383-400; C. RoBBiNs, supra note 111, Pocock, Machiavelli, Harrington, and English Political Ideologies in the Eighteenth Century, in Politics, Language, and Time: Essays on Political ThOUGHT AND History 104 (1971). 
but not to the further idea that one branch should be able to veto the actions of others. As for Bentham, the same egoistic premises about human motivation that led Hobbes to advocate absolute and unmixed monarchy eventually led the founder of utilitarianism to advocate absolute and unmixed democracy. ${ }^{140}$ These two seemingly polar positions had one thing in common (besides their motivational premises): Both flatly rejected the idea of government as a complex mixture of mutually restraining elements. Bentham's radically majoritarian reforms, supported by other liberals as well, paved the way for the ultimate abandonment of mixed government in favor of parliamentary supremacy, effectively unicameral, and largely devoid of those monarchical and aristocratic elements that had formerly provided mixture, checks, and balance.

To assert, however, that the liberal tradition was hostile to checks and balances would be going much too far, especially since, as already noted, ${ }^{141}$ many of the writers (including "Cato," Burgh, Priestley, and Price) now classified as belonging to the republican tradition because of their defense of civic virtue against corruption, held Lockean views on other subjects, such as the origins and proper limits of government, the social contract, natural rights, and (pre-political) liberty, and could therefore properly be placed in the liberal tradition as well. A fair conclusion, perhaps, is that Tushnet's apparent view that liberalism was strongly committed to institutional constraints and republicanism only weakly so would be more accurate if reversed.

\section{Selfish Human Nature: Not Only a Liberal Idea}

Given that neither judicial review itself nor the larger concept of checks and balances was in any significant way a product of the liberal tradition, can it be argued nonetheless that the possessive individualism of Hobbes and Locke at least provided a theory of human nature from which one could logically infer, and from which the framers did infer, the danger of legislative tyranny and consequently the necessity for judicial review? This argument, too, must be rejected, on two grounds.

First, these assumptions about human nature were by no means exclusively liberal. Second, the framers did not derive judicial review from those premises and, in any event, do not appear to have assigned judicial review the central role in the constitutional structure that Tushnet claims the "liberal tradition" assigned it. The first point will be discussed in this section; the second in Section E.

140 See C. Weston, supra note 132, at 217, 234-38.

141 See supra note 111 and accompanying text. 
The image of human nature as passionately selfish and greedy for wealth and power long antedated liberalism. The Christian tradition, with its doctrine of original sin, had etched that image deeply into the Western mind. Generations of Protestant churchgoers on both sides of the Atlantic needed no reminder from Thomas Hobbes of the failings of fallen man.

Among political thinkers, those of the republican tradition yielded to no one in the harshness with which they described elementary humanity. Machiavelli observed that ". . . in constituting and legislating for a commonwealth it must needs be taken for granted that all men are wicked and that they will always give vent to the malignity that is in their minds when opportunity offers."142 $\mathrm{He}$ further noted that "men never do good unless necessity drives them to it; but when they are too free to choose and can do just as they please, confusion and disorder become everywhere rampant."143

Similar opprobria parade through the pages of the English radicals and "commonwealthmen" who spoke for the civic republican tradition in the seventeenth and early eighteenth centuries. ${ }^{144}$ Cato's Letters struck a characteristic note: "[A]s selfishness is the strongest bias of men, any man ought to be upon his guard against another, that he become not the prey of another... Men are very bad where they dare, and ... all men would be tyrants and do what they please." Nevertheless, Cato concluded:

$[T]$ he lot of humanity being an unhappy one, it is an honest ambition, that of endeavoring to mend it, to improve nature by virtue, and to mend mankind by obliging them to observe rules that are good. We do not expect philosophical virtue from them; but only that they follow virtue as their interest and find penal and dangerous to depart from it. And this is the only virtue that the world wants, and the only virtue it can turn to. ${ }^{145}$

As applied to these nostalgic Britons, Tushnet's concession that the republican tradition "did not romanticize human nature"146 is a considerable understatement. These men (as we have noted), ${ }^{147}$ members of the extreme opposition to the Walpole ministry, denounced its successful efforts to corrupt members of Parliament, efforts that had destroyed

142 N. Machiavel.L, supra note 133, bk. I, ch. 3, at 111-12.

143 Id. at 112.

144 See I. KRAMNICK, supra note 132, at 238-39, 250, 259.

145 Cato's LeTTERS, supra note 65, at 53, 55.

$146 \mathrm{M}$. TushNET, supra note 2 , at 11 .

147 See supra notes 138-39 and accompanying text. 
the delicate balance of their ancient and beloved constitution. They saw this corruption as pervasive in their society, associated it with the rise of commerce and finance, and thought it a manifestation of basic human nature, if only one side of it. They believed civic virtue to be possible, at least for the landed gentry to whom alone they were willing to entrust the rights and duties of self-government, but they opposed extension of the franchise to the newly enriched bourgeoisie. They knew that civic virtue had flourished at glorious moments of the past-in Athens, Sparta, republican Rome, and perhaps in happier days under their own ancient constitution-but they had no illusion that it reigned in their own time and place. Civic virtue for them was not a wildflower but a hothouse plant, needing just the right conditions in order to thrive, conditions that did not exist in the England in which they lived.

Whig-minded Americans of the 1760 s and 1770 s were perhaps more optimistic. While they saw corruption and vice in their own society, and associated it with the unwelcome rise of commerce, they also saw a way out: a decisive break with the mother country that would, they believed, usher in a moral as well as a political reformation. ${ }^{148}$ By 1787, however, those expectations had been dampened, and the need for institutional constraints on the exercise of power had become more apparent than ever, even to those champions of civic virtue who wrote and secured the ratification of the new constitution. ${ }^{149}$

In sum, "the liberal tradition" had no monopoly on pessimism or "realism." The obsessive fear that unchecked power would be abused and turned to private ends that dominated the Whig tradition of political writing throughout the century leading up to our revolution was shared by nearly all politically conscious Americans. This is true whether their insights came from Machiavelli, from Montesquieu, from Locke, or from all of them. And their remedy-a constitutional system of checks and balances-was, as we have seen, every bit as much, or even more, a republican remedy than a liberal one.

If republican thinkers had no illusions about the darkly individualistic aspects of human nature, liberal thinkers, in this respect deviating from Hobbes, were not unaware of the social aspects. Recent scholarship on Locke, as Tushnet acknowledges, ${ }^{150}$ has tended to emphasize the non-individualistic, i.e., the religious, altruistic, and communal aspects of his political thought. ${ }^{151}$ For Locke, unlike Hobbes, man's pre-

148 See G. Woon, supra note 112 , at 91-124 (1969).

149 See infra note 171 and accompanying text.

150 See M. TushNET, supra note 2 , at 4-5 n.9.

151 See R. Ashcraft, Locke's Two Treatises of Government 97-121 
political condition, the "state of nature," was not one of universal enmity, a war of all against all. Human beings, the "workmanship" of God, were bound together by the mutual obligations of natural law. Each was required by that law not only to preserve himself, but, "as much as he can, to preserve the rest of mankind." "152 Locke speaks of men as "sharing all in one community of nature"; 153 of reason as "the common bond whereby human kind is united into one fellowship and society"; ;64 and of the "great and natural community" to which all men belong by virtue of the law of nature ${ }^{155}$ and under which "all men alike are friends of one another and are bound together by common interests."156

This is not to suggest that Locke was a closet communitarian or anything approaching it; his individualism differs from that of Hobbes only in degree. But the degree is important. It enabled Locke to attribute to human behavior a greater measure of trustworthiness than Hobbes could, and in particular, to expect those entrusted with limited power for the good of the community to exercise it responsibly most of the time. The motives that might induce such trustworthy behavior included religion, positive law, concern for reputation, natural sociality. ${ }^{187}$ Although recognizing that trust reposed in the governors might sometimes be violated, and that persistent violation would entitle the community to reclaim the abused power, there is no indication that he believed, and nothing in his philosophy implied, that such derelictions would be frequent or pervasive.

Nor was Locke the only classical liberal thinker whose individualism was tempered by glimmerings of altruism. Adam Smith began his "other" masterpiece, The Theory of Moral Sentiments, with the observation: "How selfish soever man may be supposed, there are evidently some principles in his nature, which interest him in the fortune of others, and render their happiness necessary to him, though he derives nothing from it except the pleasure of seeing it." ${ }^{\text {"158 }}$ Smith went on to attribute the elementary human emotions of pity, compassion, benevolence, and the sense of justice to the principle of "sympathy": our ca-

(1987); J. Dunn, The Political Thought of John Locke (1969); J. Tully, A Discourse on Property: JoHN Locke and His Adversaries (1982); Dunn, 'Trust' in the Politics of John Locke, in Rethinking Modern Political Theory 34 (1985).

152 J. Locke, supra note 43 , at II, $\S 6$, at 311.

183 Id.

154 Id. at II, \& 172, at 430 .

185 Id. at II, § 128, at 397.

158 J. Locke, Essays on the Law of Nature 163 (W. von Leyden ed. 1954).

107 See Dunn, supra note 151, at 34, 46-47.

158 The Essential Adam Smith 65 (R.L. Heilbroner ed. 1986). 
pacity to imagine the happiness or suffering of others as though it was our own, to "[change] places in fancy with the sufferer."158 In language that might have been used by Machiavelli to describe the man of civic virtue, Smith writes:

The love of our country seems, in ordinary cases, to involve in it two different principles; first, a certain respect and reverence for that constitution a form of government which is actually established; and secondly, an earnest desire to render the condition of our fellow-citizens as safe, respectable, and happy, as we can. He is not a citizen who is not disposed to respect the laws and obey the civil magistrate; and he is certainly not a good citizen who does not work to promote, by every means in his power, the welfare of the whole society of his fellow citizens. ${ }^{160}$

If liberal and republican political theorists did not differ fundamentally in their empirical descriptions of human behavior, did they differ at least in their normative attitudes toward the obligations of citizenship and governance? In part they did. Although modern liberal theorists, John Stuart Mill and his successors, valued political participation as a means of individual self-fulfillment, ${ }^{\mathbf{1 6 1}}$ it is fair to say that their seventeenth and eighteenth century predecessors, with rare exceptions, ${ }^{\mathbf{1 6 2}}$ did not. Those holding political power, however, were expected to act in the public interest. For Locke, as we have seen, the power of the state was a trust to be exercised for the general good. For Bentham "the right and proper end of government in every political community is the greatest happiness of all the individuals of which it is composed,"163 and those in power are obligated to act accordingly. The problem of institutional design was to structure incentives, mainly through the ballot box, so that self-interested governors would conform their conduct to this "greatest happiness" norm. Although liberal economic theory held that the public good would be promoted as an unconscious byproduct of countless decisions by individuals pursuing their own advantage in the marketplace, and although liberal political theory

159 Id. at 66.

160 Id. at 138.

161 See G.F. Gaus, The Modern Liberal Theory of Man 204-28 (1983).

162 Richard Price, a late eighteenth century Lockean, anticipated Mill's emphasis on participation for the sake of personal growth. See Price, Additional Observations on the Nature and Value of Civil Liberty and the War with America, in RICHARD PRICE and THE ETHICAL Foundations of the American Revolution 125, 144, 149 (B. Peach ed. 1979); see also D.O. Thomas, The Honest Mind: The Thought and WORK OF RICHARD PRICE 193 (1977).

${ }_{163} 9$ The Works of Jeremy Bentham 5 (J. Bowring ed. 1962). 
may have entertained a similar idea about the voting behavior of the governed, the conduct of the governors was viewed differently: As to them, liberal political theory was not content to rely on the dexterity of the invisible hand. Each officeholder was expected to work for the collective good, if only as a means of promoting his own. In essence, liberalism, like republicanism, called on judges and legislators to display civic virtue, though the term was not part of the liberal vocabulary.

When it is observed that the liberal tradition, too, valued publicminded behavior on the part of those holding government power, the normative difference between it and the republican tradition begins to narrow. It narrows further when it is also recognized that the civic virtue prized by republican traditionalists was not without its own utilitarian and self-interested dimensions. As Tushnet acknowledges, civic virtue was not expected of men and women who depended on others for their livelihood or well-being; hence the need for wide diffusion of property if a contemporary republican revival is to be at all possible. ${ }^{\mathbf{1 6 4}}$ Thus, even for republicans, institutions had to be arranged so as to moderate the conflict between self-interest and public interest if the latter motive were to have any chance of prevailing. In the case of the judiciary, Tushnet says that the framers, pursuant to the republican tradition, attempted to create the necessary independence, and thus make possible the desired civic motivation, by granting permanency of tenure. A follower of Hobbes or Bentham might describe and defend this same institutional arrangement as a means of relieving the pressure of certain selfish appetites, that is, for money, power and security, in order that other appetites, that is, for public approval and esteem or the satisfaction of a job well-done, might rise to the top. The civic humanist and the utilitarian liberal, albeit using differing vocabularies, not only end up justifying the same institutional device, but assign to it an essentially similar purpose and expect from it much the same empirical results.

It may be answered, finally, that at least the judge or citizen who does have the requisite independence, and does therefore exercise civic virtue, is acting from a very different kind of motive than the self-interested actor envisioned by the followers of Hobbes or Bentham. Yet even this distinction is vulnerable. Civic virtue, as we have seen, ${ }^{165}$ was understood by some writers of the republican tradition not as a manifestation of innate human sociality but as a self-regarding expression of the

${ }^{164}$ See M. TuSHNET, supra note 2, at 14-15. One suspects that in the minds of landed gentlemen, on both sides of the Atlantic, a certain amount of leisure may also have been thought prerequisite to full-fledged participation in public life.

165 See supra notes 63-68 and accompanying text. 
actor's desire for fame or public esteem.

\section{E. The Framers and Judicial Review}

The preceding section argued against a simplistic dichotomy between a liberal tradition of "possessive individualism" and the republican tradition's supposedly more benign view of human nature. It thus placed an exclamation mark after Tushnet's accurate observation that the two traditions differed only in emphasis, and it located that difference primarily at the normative level, though with some hesitation even there. In this section, I dispute the proposition that the Hobbesian vision of human nature-c"possessive individualism"-led the framers to fear legislative tyranny and thus to adopt judicial review as their chosen remedy for this evil. Three points will be made. First, the Hobbesian strand of the liberal tradition was not a particularly influential factor in the political thinking of eighteenth century Americans. Second, the framers' fear of legislative excess was due far less to philosophical assumptions about human nature, Hobbesian or otherwise, than to their immediate political experience in state government during the 1780 s. Third, the framers did not, in any event, look to judicial review as the primary line of defense against legislative tyranny.

\section{The Non-influence of Possessive Individualism}

Tushnet's premise that the "liberal tradition" was one of the two great wells of ideas that the framers of the Constitution had to draw upon is clearly right if we think of the liberal tradition as the set of ideas contained in the Declaration of Independence-prepolitical rights, consent of the governed, justified revolution, and the like. But it is not at all clearly right if, like Tushnet, one thinks of liberalism instead as possessive individualism. Hobbes had little direct influence on political philosophers of his own (seventeenth) century or of the next: His political absolutism, materialism, and graphically repellent portrait of human nature were more than they could stomach. ${ }^{166}$ Americans of the

166 See J. Bowle, Hobbes and His Critics: A Study in Seventeenth CenTURY Constirutionalism 193 (1951); C.B. MACPHERSON, supra, note 9, at 90-91 (“. . . Hobbes's doctrine was not accepted by any significant group or movement in England in his own century. Neither royalists nor parliamentarians, neither Whigs nor Tories, could stomach it."); S. Mintz, The Hunting of Leviathan: Seventeenth Century Reactions to the Materialism and Moral Philosophy of Thomas HOBBES 147 (1962) ("The truth is that Hobbes's influence on his countrymen during his own lifetime and for almost a century after was negative. He left no disciples. He founded no school. He made no such impact on English thought as did Bacon. . .or as did Newton or Locke, whose influence was felt throughout the eighteenth century."). 
revolutionary generation cited him only to knock him down. ${ }^{\mathbf{1 6 7}}$ Even Locke's influence on eighteenth century political thought has become a matter of controversy among recent historians. ${ }^{168}$ Suffice it for our purposes that the Lockean ideas chiefly cited by Americans of the revolutionary generation were not those Locke had in common with Hobbes-in short, possessive individualism-but those that separated them: natural rights, a version of the social contract that bound sovereign as well as subject and imposed limits as well as conferring legitimacy on the state; and a justification for revolution if those limits were transgressed. Then, as now, possessive individualism, featuring the idea of self-interest as the wellspring of human behavior, was important to economic theorists-Adam Smith's The Wealth of Nations was published in 1776-but those theorists had scarcely anything to say about political or constitutional issues and therefore little impact on the working minds of the framers. Madison's famous discussion of faction in The Federalist No. 10 and his statement in The Federalist No. 51 that "[a]mbition must be made to counteract ambition"169 have been attributed by some to the liberal tradition, but they are more persuasively traced to David Hume, an ambiguous figure who resists easy labelling. ${ }^{170}$

167 See C. Rossiter, supra note 111 , at 357.

${ }^{168}$ Until about twenty years ago, the immensity of Locke's influence on American political thought was unchallenged. As Louis Hartz observed in 1955, "Locke dominates American political thought, as no thinker anywhere dominates the political thought of a nation." L. Hartz, The Liberal Tradition in AMERICA: AN INTERpretation of American Political Thought Since the Revolution 140 (1955). In the last two decades, however, republican revisionists have replaced liberalism with civic humanism as the major influence on the eighteenth century American political mind. The eclipse of Locke began in England with John Dunn, who argued that Locke's. political writings were little read on either side of the Atlantic throughout most of the eighteenth century, see Dunn, The Politics of Locke in England and America in the Eighteenth Century, in John Locke: Problems and Perspectives 45 (J. Yolton ed. 1969), and continued in the works of Bailyn, see B. BarlyN, THE Origins of American Politics ix-x, 56-58 (1968); Wood, see G. Wood, supra note 112, at 29; and Pocock, see J.G.A. Pocock, supra note 132, at 424; Pocock, The Myth of John Locke and the Obsession with Liberalism, in JoHN Locke 3 (J.G.A. Pocock \& R. Ashcraft eds. (1980); Pocock, supra note 139, at 144. More recently still, however, liberal re-revisionists have somewhat rehabilitated Locke's influence, at least for the later eighteenth century, both in England and America. See Appleby, The Social Origins of American Revolutionary Ideology, 64 J. OF AM. Hist. 935, 936-37, 947 (1977); Kramnick, supra note 111, at 629.

169 The Federalist, supra note 1, at No. 51 (J. Madison). $190-92$.

170 See D. ADAIR, supra note 67, at 93-106; G. WILLs, supra note 70, at 21-23, 


\section{Fear of Legislative Tyranny: Born of Experience, Not Abstraction}

The fear of legislative tyranny, widespread among Americans of the 1780 s, was inspired not so much by abstract conceptions of human nature or by the reading of political philosophy as by their own disheartening experience of political events. The euphoria of 1776 at the prospect of building a new republican society had given way by 1787 to profound disillusionment at the many legislative abuses committed by nearly all the state assemblies during the intervening decade, including ex post facto laws, property confiscations, paper money schemes, the raising of obstacles to debt collection, and interference with judges. The original fear of a strong executive had been replaced by an equally strong fear of legislative majorities, and of the popular majorities whom they represented sometimes all too well. In the view of some historians, it was these state legislative abuses, as much as the inadequacies of the Articles of Confederation, that brought the delegates to Philadelphia. ${ }^{171}$

\section{Judicial Review: Never Intended to Play the Role?}

At all events, there is little evidence that the framers, whatever their intellectual sources, attached critical importance to judicial review as a check against legislative tyranny. For that matter, some respected scholars have denied that the framers contemplated judicial review at all. ${ }^{172}$ The weight of the evidence is that many of them assumed, or realized that others assumed, that courts would have the power to disregard federal statutes determined in the course of litigation to be at odds with the Constitution; and as to state legislation, the language of the supremacy clause left no reasonable doubt. But this is a far cry from saying that the framers, without mentioning it explicitly, designed judicial review as a vital structural pillar in the constitutional edifice and assigned it the Herculean role that, according to Tushnet, the liberal tradition requires it to play.

171 See F. McDonald, Novus Ordo Seclorum 152-79 (1985); G. Wood, supra note 112, at 393-425, 471-75. Writing to Jefferson in the fall of 1787, Madison observed that the injustice of the laws of the states had been "so frequent and so flagrant as to alarm the most steadfast friends of Republicanism" and that "the evils issuing from these sources contributed more to that uneasiness which produced the Convention, and prepared the public mind for a general reform, than those which ac- crued to our national character and interest from the inadequacy of the Confederation to its immediate objects." Letter from James Madison to Thomas Jefferson (October 24, 1787), reprinted in The PApers of James MAdison 212 (R. Rutland et al. eds. 1977).

172 See, e.g., 1 L. Boudin, Government by Judiciary (1932). 
The few references to judicial review at the Philadelphia Convention were casual comments, mainly in connection with the rejected proposal to create a Council of Revision (comprising members of both the executive and judicial branches) to review congressional enactments before they became effective. Several delegates stated that because the Supreme Court would have the power to review the constitutionality of statutes in ordinary litigation, the proposed Council was either unnecessary (said some) or potentially biasing (said others). ${ }^{173}$ These statements indicate that at least some of the delegates assumed the existence of judicial review, but they are not evidence (one way or another) that anyone attached great importance to it.

The subject of judicial review received little attention in the ratification debates. Madison's classic analyses of the problem of legislative tyranny (or "majority faction" as he called it) in The Federalist Nos. 10 and 51 do not mention judicial review among the solutions. Number 10 relied exclusively on political economies of scale-the role of large population and extensive territory as an impediment to the formation of potentially oppressive majority coalitions. ${ }^{174}$ Number 51 explained that the division of the Congress into two bodies, and the power of veto in the hands of the president, would go far toward diluting the threat of legislative abuse. ${ }^{175}$ To be sure, we know that Madison favored additional checks that were rejected in Philadelphia: the Council of Revision and also a federal veto on state legislation. ${ }^{176}$ But the very fact that, wanting more constraints than he was able to get, Madison didn't bother to note one that he had-judicial review-suggests how little reliance he placed on it.

The only full-fledged justification of judicial review in the whole of the ratification debates was Hamilton's celebrated exposition in The Federalist No. $78 .^{177}$ Anticipating Marshall's rationale in Marbury $v$. Madison, ${ }^{178}$ Hamilton argued that the "interpretation of the laws is the proper and peculiar province of the courts" and that the constitution is a law, a "fundamental law."179 Judicial review, in other words, is simply an unremarkable part of the everyday function of judging. This, no doubt, is the basis for Tushnet's own conclusion, alluded to earlier, that the framers had a modest conception of judicial review drawn from the republican tradition in contradistinction to the liberal.

173 See R. BERger, supra note 125 , at $49-72$.

174 The Federalist, supra note 1, at No. 10 (J. Madison).

175 See id. at No. 51 (J. Madison).

176 See R. Berger, supra note 125 , at $72,74$.

177 See The Federalist, supra note 1, at No. 78 (A. Hamilton).

1785 U.S. (1 Granch) 137 (1803).

178 The Federalist, supra note 1, at No. 78 (A. Hamilton). 
The Federalist No. 78 contains other language, however, describing the important political function of judicial review as part of the constitutional system of checks and balances. Hamilton refers to the courts as "bulwarks of a limited Constitution against legislative encroachments";180 as having been "designed to be an intermediate body between the people and the legislature in order, among other things, to keep the latter within the limits assigned to their authority";181 and, most important, as guarding

the Constitution and the rights of individuals from the effects of those ill humors which the arts of designing men, or the influence of particular conjunctures, sometimes disseminate among the people themselves, and which, though they speedily give place to better information, and more deliberate reflection, have a tendency, in the meantime, to occasion dangerous innovations in the government, and serious oppressions of the minor party in the community. ${ }^{182}$

Even when they reflect the majority will, such laws must be disregarded if they are "incompatible with the provisions of the existing Constitution."183 Moreover, even when "unjust and partial" laws are not unconstitutional, judges, by "mitigating the severity and confining the operation" of those laws (presumably through statutory construction, lenient sentencing, and perhaps even the judicial equivalent of jury nullification), may operate "as a check upon the legislative body" and deter them from further mischief. ${ }^{184}$

These passages reflect Hamilton's vision of the courts' role as an integral part of the governmental system, a check against abusive legislation, whether or not unconstitutional. But the passages that tell us this also tell us something else. Hamilton recognized that a law could be "unjust and partial," an instance of majority faction (in Madison's sense), or legislative tyranny (in Tushnet's) without being unconstitutional; and, further, that such a law would be beyond the reach of judicial review, though still capable of being "mitigated" or "confined" by other means. Clearly he did not regard judicial review as a cure-all for oppressive legislation. Nor did he regard the prospect of such legislation as anything other than a temporary aberration.

Tushnet, as I have noted already, probably would have little quar- 
rel with this analysis. He does not say that the framers themselves had great expectations of, or placed heavy burdens on, the institution of judicial review. On the contrary, he claims, for the most part, that they looked at this institution through the rose-colored glasses of the republican tradition and believed it would perform, and would only be called on to perform, a fairly minor role. Judges selected from a nationwide pool and given guarantees of tenure would interpret a constitution that has a "plain meaning," enforcing its "readily understood" terms in such a way as to catch the infrequent lapses of a legislature itself generally public-minded and only occasionally led astray by corruption. $\mathrm{He}$ tells us that these optimistic assumptions of relatively virtuous legislators, even more virtuous judges, and "plain meaning" were drawn from the republican tradition, not the liberal. True, Tushnet also asserts that the framers drew from both wells, and that liberalism required institutional constraints even more urgently than did republicanism, though both were served by them. Yet, he seems to conclude, the framers' demands of and expectations for these institutions, including judicial review, were, in the end, precisely what they would have been had the framers drawn only from the republican tradition and rejected Hobbesian assumptions altogether.

\section{F. The Framers and "Plain Meaning"}

In one matter, Tushnet is on weaker ground: his assertion that the framers thought the Constitution would have a "plain meaning" and that "judges will therefore enforce the terms of a readily understood Constitution." publican tradition, claiming that it "had available a theory of constitutional interpretation," as "the liberal tradition did not." evidence he offers is that:

Marshall thought that he clinched his argument in Marbury v. Madison by listing three provisions and implying that it would be absurd to hold that judges could not invalidate "a duty on the export of cotton" or "such a bill" of attainder or a statute declaring that "one witness [would be] sufficient for conviction" of treason. ${ }^{187}$

Modern readers, says Tushnet, may wonder why the Court's determination that a piece of legislation is "such a bill" should prevail

$185 \mathrm{M}$. TushnET, supra note 2 , at 13 .

188 Id.

${ }^{187}$ Id. at 12 (quoting Marbury v. Madison, 5 U.S. (1 Granch) 137, 179 (1803)). 
over the legislature's determination that it is not. The contemporary answer, he suggests, was that "in the eyes of those in the republican tradition, the limits the Constitution places on the government are stated in terms whose meaning is readily understood within the relevant communities."188 The "plain meaning" idea has become "implausible," Tushnet explains, because of the framers' commitment to private property and, presumably, the dynamics of economic growth.

Can it really be true that many of the framers held so simplistic a view of the problem of constitutional construction and that those who held it were republicans but not liberals? That claim is implausible on its face, and Tushnet gives us no reason to credit it. Marshall's reliance in Marbury on the three "clear" provisions certainly did not imply a belief that all provisions, or even all prohibitions, in the Constitution were unambiguous, or even that the selected provisions were unambiguous in all applications. By 1803, when Marshall wrote Marbury, it had become abundantly clear that the new Constitution would present intensely controversial issues of interpretation. The enactment by the first Congress in 1789 of a bill to establish a national bank led to memorable debate within President Washington's cabinet-as to the validity of that law, with Hamilton and Jefferson arguing pro and con. Four years later, the Supreme Court's decision in Chisholm v.Georgia, ${ }^{189}$ though a literal and nearly unanimous interpretation of Article III, "fell upon the country with a profound shock" and triggered the immediate adoption of an overruling constitutional amendment. ${ }^{190}$ In 1898, the passage of the Alien and Sedition Acts by a Federalist-dominated Congress set off a bitter partisan debate over the constitutionality of that legislation, raising among others, fundamental issues as to the meaning of the first amendment. Thus, by 1803 only a sleep-walker could have thought the Constitution "readily understandable."

Whatever may have been true by 1803 , is it not possible that in 1787 the Constitution's potential for ambiguity was not yet appreciated? Jefferson Powell's recent and illuminating article on the original understanding of "original intent,"181 cited by Tushnet in support of his statement of the "republican" theory of interpretation, ${ }^{\mathbf{1 9 2}}$ actually presents strong evidence against the notion that the Constitution was thought to have a "plain meaning." Powell's thesis was that the fram-

$188 I d$.

1892 U.S. (2 Dahl.) 419 (1793).

190 C. Warren, The Supreme Court in United States History (1926).

191 See Powell, The Original Understanding of Original Intent, $98 \mathrm{HARv}$. L. REV. 885 (1985).

192 See M. Tushnet, supra note 2 , at 12 n.33. 
ers expected future interpreters to look for the meaning of the Constitution in the text itself, not the framers' subjective intent. ${ }^{193}$ But in accepting "the common law's objective approach to discerning the meaning of a document," the framers did not endorse strict literalism as the proper stance of future interpreters. They were "aware that unforeseen situations would arise, and they accepted the inevitability and propriety of construction."194 Putting this point in wider focus, Powell argues that the Americans who wrote, debated, opposed, and ratified the Constitution drew upon two divergent approaches to the interpretation of texts. One, with sources in British Protestantism and Enlightenment rationalism, opposed any and all methods of "construction" in favor of a strict textual literalism. The other was willing to interpret the constitutional text in accordance with the methods and principles traditionally used by the common law to interpret statutes. Powell makes clear that the Philadelphia framers, most well-schooled in the common law tradition, held to the second, pro-construction, point of view. ${ }^{196}$ This point of view does not coincide with, and if anything seems contrary to, Tushnet's description of republican confidence in textual clarity. Just how difficult or controversial the framers expected future questions of construction to be is unclear, but their attitude may have been reflected in a retrospective comment by James Madison in a letter he wrote to Judge Spencer Roane in 1819:

It could not but happen, and was foreseen at the birth of the Constitution, that difficulties and differences of opinion might occasionally arise in expounding terms and phrases necessarily used in such a charter . . . and that it might require a regular course of practice to liquidate and settle the meaning of some of them. ${ }^{198}$

Lest it be thought that Madison's recollection benefited from hindsight, it is useful to quote what seems a very similar view in his The

193 See Powell, supra note 191, at 888.

194 Id. at 904.

195 See id. at 904.

${ }^{198}$ Letter from James Madison to Judge Spencer Roane (Sept. 2, 1819), reprinted in The Mind of THE Founder: Sources of The Pol.rTical Thought of James Madison, at 361 (M. Meyers ed. 1981). On the other hand, Madison went on to say: "But it was anticipated I believe by few if any of the friends of the Constitution, that a rule of construction would be introduced as broad and as pliant as what has occurred" [in McCulloch v. Maryland, 17 U.S. (4 Wheat.) 316 (1819)]. Assuming the accuracy of Madison's recollection, this would suggest that the framers anticipated a flexibility of construction somewhere between "plain meaning" and the sweeping breadth of Marshall's McCulloch opinion. 
Federalist No. 37:

All new laws, though penned with the greatest technical skill and passed on the fullest and most mature deliberation, are considered as more or less obscure and equivocal, until their meaning be liquidated and ascertained by a series of particular discussions and adjudications. Besides the obscurity arising from the complexity of objects, and the imperfection of the human faculties, the medium through which the conceptions of men are conveyed to each other adds a fresh embarrassment. . . But no language is so copious as to supply words and phrases for every complex idea, or so correct as not to include many equivocally denoting different ideas. . . . When the Almighty himself condescends to address mankind in their own language, his meaning, luminous as it must be, is rendered $\operatorname{dim}$ and doubtful by the cloudy medium through which it is communicated..$^{197}$

There is some justification for associating the opposing anti-construction theory of textual interpretation with the republican tradition, if only that both had common roots in the "country ideology" of the radical Whig oppositionists earlier in the century. ${ }^{108}$ It would be wrong, however, to suppose that even adherents of what Powell calls the anticonstruction approach to textual interpretation believed that the Constitution lent itself to that approach and was "readily understandable." On the contrary, during the ratification period, it was mainly the AntiFederalist opponents of the Constitution who espoused the anti-construction approach, and they did so only to show that the Constitution's vague, complex, and obscure language would be an open invitation to free-wheeling and expansive interpretation by Congress and the federal courts, mainly at the expense of the states. Thus, if the republican tradition did hold that documents should have plain meaning, the Constitution was, to that extent, a most unrepublican document, for its authors, its champions, and its opponents all realized that its meaning would not always prove to be plain.

\section{G. Liberalism-as-Lived-in-the-Culture}

We are left with Tushnet's somewhat cryptic insistence that the "liberal tradition," as he uses the term, is not to be found in the works of formal political theorists (or, apparently, in any inferences drawn 
from those works by the framers) but in what he calls "amateur political theory" or "liberalism as lived and experienced in the culture."199 But he identifies no such "amateur" theorists, and I am aware of none to whom the generalizations I have made about liberal political thinkers would not likewise apply. The more significant candidate for the location of the liberal tradition is the cultural and political life of the nation, especially as it emerged in the nineteenth and twentieth centuries, after the supposed "invalidation" of the framers' cozy republican expectations for the new polity.

Here again, however, Tushnet's claim suffers severely from inadequate definition. He does not explain what he means by liberalism-aslived-in-the-culture or in what sense liberalism so defined could be said to demand any particular role for judicial review. It is particularly unclear, for example, what thoughts, if any, about judicial review Tushnet means to attribute to members of the American "culture." Tushnet would probably not wish to argue that American public opinion makes the singular demands on the institution of judicial review that he, Tushnet, claims the "liberal tradition" makes-that is, that the American people expect the Supreme Court to protect our society against all forms of legislative oppression, regardless of their relationship to the constitutional text, and including even the controversial economic policies noted by Tushnet as examples of possible legislative excess. $^{200}$ The seemingly strong popular reaction against President Reagan's nomination of Robert Bork to the Supreme Court revealed, perhaps, a greater degree of concern for certain rights and the Court's ability to protect them, a greater degree of sensitivity to the danger of legislative tyranny vis-a-vis judicial tyranny, than some had previously suspected. But even these implied judgments fall short of the demand for judicial control that Tushnet seems to think liberalism imposes. What is far more likely, I think, is that he means only that American culture and politics are permeated by the values of possessive individualism and that from this cultural and political reality there arises (whether or not anyone but Tushnet is aware of it) an objective danger of legislative tyranny, the consequent necessity of constraining judicial review, the consequent danger of judicial tyranny, and the impossibility of a constitutional theory that will simultaneously eliminate both dangers.

While it would be hard to deny that self-interest and materialism rank high among the motivating values of our society, the leap from

200 See supra notes 72-73 and accompanying text. 
this recognition to Tushnet's conclusions about tyranny and judicial review is no more easily accomplished when the premise of self-interest represents Tushnet's own empirical assessment of American reality than when it is presented as the abstract speculation of Hobbes or Locke or other liberal theorists. Furthermore, the hypothesis of possessive individualism, highly plausible when applied to behavior in the private or political (that is, voting) spheres, becomes more problematic when applied to the official conduct of those in government. "Public office is a public trust" still seems a vital principle in our society, a principle often honored in the breach but more often, I suspect, in the observance. Official corruption, frequent though it be, is subject to intense scrutiny by a vigilant investigative press, is often punished severely when exposed, and has not lost its power to shock the public. Moreover, a truly Hobbesian government could not have achieved the remarkable stability ours has; nor could it have maintained our strong tradition of civilian control. The fact that we have experienced no military takeover, or serious attempt at one, in two centuries is testimony both to the civic virtue of the officer corps and the effectiveness of the many subtle institutional constraints within our system, of which judicial review is only one and not necessarily the most important. Indeed, it is symbolically noteworthy that the most celebrated coup attempt even in our fiction was not a Hobbesian power grab but an effort by patriotic officers in the name of civic virtue itself. ${ }^{201}$

These random impressions admittedly prove little. Reasonable opinions may differ as to the relative admixture of self-interest and civic virtue in our governing institutions. On the necessity for judicial review, however, one piece of evidence seems especially probative. The fact that Great Britain, the motherland of the liberal tradition, has managed for centuries to do without judicial review, and that British political theorists, including liberals, have so little lamented its absence, cuts rather strongly against the general proposition that a modern liberal polity depends on this institution for a solution to the problem of ordered liberty.

\section{The Republican Tradition and Judicial Review}

In the concluding chapter of Red, White, and Blue, Tushnet offers us a vision of the republican society he hopes we will move toward and of the role - or, more precisely, the non-role - that judicial review and constitutional law will play in that society. The republic of

201 See F. Knebel \& C. Bailey, Seven Days in May (1962). 
Tushnet's vision is a collection of small communities - small enough for face-to-face interactions. Its decentralized institutions would be modeled on various "intentional" communities in the United States that operate on the principle of consensus/unanimity in decision-making. "[A]s the framers understood, the smaller the community, the more likely that face-to-face interactions will lead each member to understand the foibles and the contributions of the others, making it more likely than in larger groups that consensus can be reached."202

It is "not clear that the commonwealth would have a Constitution or constitutional theories of the sort we have examined." A republican constitutional theory would be "a form of civic education, part of the dialogue among citizens that creates a public," but would not be directed at judges or confer any power on them. And while the commonwealth "might be organized pursuant to a written document that speaks of institutions and rights," it would not contain a set of legal rules but merely rules of thumb that experience found useful and that acquired no binding force by being written down. ${ }^{203}$

It is worth noting once again the striking difference between the republican tradition of the eighteenth century, as Tushnet describes it in his Introduction, and the utopian republic of the twenty-first century he projects in his Conclusion. ${ }^{204}$ The eighteenth century republican tradition differed from liberalism, he tells us, only in "matters of emphasis."

The republican tradition did not envision nearly universal suffrage. The nation's population was divided into citizens and others. The others were not expected to participate in politics and so would not require the guarantees of independence that property holding provides. The republican tradition therefore did not postulate widespread property holding as a condition for ordered liberty. . . . "Noncitizens" do not have the kind of stake in republican institutions that citizens do, or that everyone does in liberal institutions. Civic education in the republican tradition would instead cultivate a culture of deference. Within the citizenry, deference to other citizens dampens self-interest and reduces the risk of corruption. Outside the citizenry, deference to superiors dampens disorderly urges. ${ }^{205}$

${ }^{202}$ M. Tushnet, supra note 2 , at 316.

203 Id. at 317.

204 See supra notes $106-110$ and accompanying text.

${ }^{205} \mathrm{M}$. TushNeT, supra note 2 , at 14. 
In short, the republican tradition of old was elitist, hierarchial and exclusionary. Its greater egalitarianism (vis-a-vis the liberal tradition) must therefore be taken with a heavy dose of salt. In Virginia or South Carolina, as in England, it was an ideology for country gentlemen.

At times, and in places, the republican tradition also had other unattractive features. It could be sexist: Machiavelli, for example, glorified the manly and martial qualities of firmness, strength, endurance, courage, and the ability to bear arms, while denigrating effeminacy and what he considered the womanly qualities of emotion, inconstancy and fickleness. ${ }^{206}$ In some versions, republicanism was puritanical, praising the Spartan attributes of austerity, frugality and industry, while disdaining luxury, extravagance, elegance and ease. ${ }^{207}$ Here and there, moreover, and most dramatically in the French revolutionary setting, an overzealous communitarianism could lead republicans in a dangerously conformist or even totalitarian direction.

I do not suggest that today's republican revivalists are saddled with historical baggage or that they are unfree to select which elements of the tradition they wish to endorse. But before any extra ideological mileage, any special legitimacy, is conferred on their enterprise by virtue of its distinguished ancestry, the ancestor should be seen whole and with warts. In particular, it should be kept in mind that civic virtue was a quality expected of the few, not the many.

Tushnet is well aware of this and does not, on the whole, idealize the republican past (except in claiming the framers' "understanding" for radical decentralization that would have appalled them). What he may be guilty of, however, is a curious double standard in treating the liberal tradition as though it began and ended with the atomism of Hobbes, as though Mill and his successors never lived, while at the same time absolving his futuristic republicanism of any connection with the sexism of Machiavelli, the elitism of the Whig (and Virginia) gentry, or the terrible conformism of the Jacobins.

Putting aside these historical questions, let us examine Tushnet's utopian conception in its own terms. Tushnet does not explain precisely why judicial review, or other institutional constraints, would be unnecessary in a republican society. There are several possible reasons. First, laws of the sort deemed tyrannical in our society would not be enacted by a republican legislature because they would be contrary to "public

${ }^{206}$ See F. McDonald, supra note 171 , at $70-71,74$; H. Pitkin, Fortune is a Woman: Gender and Politics in the Thought of Niccolo Machiavelli 8, $22,25,110-12,144$ (1984).

${ }_{207}$ See, e.g., F. MCDONALD, supra note 171, at 70-74; G. Wood, supra note 112 , at $114-18$. 
values." Second, such laws, even if enacted, would have the unanimous or near-unanimous support of republican legislators and citizens. Third, and perhaps most plausible, judicial second-guessing of such a process would be either redundant or illegitimate. The judicial and legislative inquiries, both animated by concern for the public interest, would be highly likely to yield the same conclusion, and if not, there would be no justification for preferring the judges' assessment of the public interest to that of the legislators. None of these arguments, even the last, is convincing.

In what follows I propose to consider three questions. (1) Would the public values of our New Republic dictate non-controversial, and non-tyrannical, answers to the legislative issues that have most troubled our recent constitutional discourse? (2) Would civic virtue plus the miniaturization of decision-making units create a politics of consensus or unanimity that would justify dispensing with the Constitution and judicial review? (3) Would the efflorescence of civic virtue at the legislative level, in and of itself, eliminate the difference in perspective between legislature and judiciary-and thus make judicial review an exercise both redundant and illegitimate?

\section{A. Would civic virtue and public values resolve our present controversies?}

The prospect that republican values and republican processes would often produce legislative outcomes fundamentally different from or less controversial than those that have fueled constitutional debates in recent years seems most unlikely. Such concepts as civic virtue, rational dialogue, participation, and mutual forbearance-indeed, even equality-do not have concrete substantive implications powerful or predictable enough to accomplish this. Let us look briefly at some of the issues that the Supreme Court has found most troublesome and imagine how they would be approached in the New Republic contemplated by Tushnet (ignoring, for the present, his assumption of decentralized decision units).

\section{Abortion}

If the transformation in civic attitudes implicit in the republican vision were accompanied by a greater sense of responsibility in private relationships as well, fewer abortions would be demanded. (A cynic might add that intense concentration on political issues and frequent attendance at public meetings would leave little time, strength, or appetite for the private pursuits that generate fetuses.) The abortion phe- 
nomenon, however, would not disappear altogether, and the appropriate legislative response would continue to be an issue. Some republicans, devaluing privacy, and regarding abortion as a form of self-indulgence, would favor prohibition. ${ }^{208}$ Others would oppose prohibition as an expression of male domination aimed at keeping women in their traditional place and exluding them from the public life of the community; or on various utilitarian grounds-population control, family stability, female access to the job market. Still others, having no strong preference between the pro-life and pro-choice positions, and putting the interest of social harmony ahead of both, would press for a compromise or cast their lot with the side that seemed more numerous, more intense, or less unforgiving. All in all, though, the republican dialogue would not be very different from the one to which we have become accustomed.

\section{Homosexuality}

Other issues of privacy, such as the legal status of homosexuality, would be equally controversial. Many republicans would sign on to Patrick Devlin's argument ${ }^{209}$ that a society has the right to enforce its collective sexual morality even against conduct harmless to others in John Stuart Mill's sense. Other republicans might argue instead that the public interest is better served by a community ethic of respect, toleration, and empathy than by an ethic of conformity, or that collective denigration of homosexuality as a way of life deprives its victims of important aspects "due citizenship."210 The debate might take a slightly different form than the one that engaged Lord Devlin and Professor H.L.A Hart ${ }^{211}$ (carrying Mill's liberal banner) a quarter century ago. But debate there would certainly be, and no assurance that legal burdens on homosexuals would be lighter than those they currently bear.

208 This is not to say that republicanism, in its commitment to the public life, is fundamentally and necessarily hostile to the values of privacy. Frank Michelman has recently articulated a republican vision of "privacy as a political right" in which "the principles of personal refuge and intimacy" are seen as underpinning, like property rights, "the independence and authenticity of the citizen's contribution to the collective determinations of public life." Michelman, Law's Republic, 97 YALE L.J. 1493, 1535 (1988).

${ }^{209}$ See P. Devlin, The Enforcement of Morals 1-25, 102-39 (1965).

210 See Michelman, supra note 208, at 1533.

211 See H.L.A. HaRt, LAw, Liberty and Morality (1963). 


\section{Pornography and Group Defamation}

Both liberals and republicans are committed to a process of open and uninhibited political discourse. But since republicans place less value than liberals on freedom of expression as a non-political right, laws regulating pornography, private defamation, and commercial advertising in the interest of competing social values might fare better in a civic republic than in ours. Pornographic speech that is thought to debase women would be particularly abhorrent to republicans because of its contribution to what they see as a hierarchial system of male domination. On similar grounds, they would be especially hostile to racist speech, sometimes called group libel. On the other hand, republicans, being more reluctant than liberals to draw public/private, or political/ non-political lines, and conceiving politics as the process by which all our values and preferences are formed, would be hard pressed to deny that pornography and group libel are part of that value-formation process. They would be confronted with a dilemma: to ban this speech and thus purge the political dialogue of elements of domination, or to tolerate it and thus preserve the openness and robustness of the process. The one option not open would be to classify it as non-political speech and thus fair game. The best hope, perhaps, is that a civic republic would be a kinder, gentler, more mutually respectful society from which contemptuous forms of interchange would depart even without legal compulsion.

\section{Individual Defamation}

Defamation of individuals would present a similar problem. Perhaps there would be less of it in a republican society: Civic virtue, one hopes, would evoke a more scrupulous attention to accuracy and fairness, causing newspapers to worry less about circulation figures and more about the quality of their contribution to the public dialogue. On the other hand, nothing is more likely to produce passionately selfrighteous finger-pointing than a strong sense of one's own civic virtue and other people's lack of it. As a legislative matter the proper balance between free speech and reputation would be as lively and difficult an issue in a republican society as it is in ours. Some republicans, believing strongly in robustness and breathing room, might favor legislation such as the Supreme Court passed in New York Times $v$. Sullivan. ${ }^{212}$ Others might throw in with Machiavelli when he warned "in what detestation calumnies should be held in free cities and in all other forms 
of society, and how with a view to checking them no institution which serves this end should be neglected."213

\section{Religion}

In matters touching church and state, republican attitudes would be equally difficult to predict. Tushnet implies that civic republicans, with their greater sympathy for "intermediate institutions," might be more accommodating than the present Supreme Court to the interests of religion-permitting, for example, prayer in the public schools and state assistance to parochial schools. ${ }^{214}$ It is equally likely, however, that republicans, associating themselves with the values of national unity and integration, and believing private and parochial schools to be a divisive influence, would favor their abolition altogether. In a civic republic, the first casualty might not be Schemp $p^{215}$ or Lemon, ${ }^{216}$ but Pierce v. Society of Sisters. ${ }^{217}$

\section{Affirmative Action}

We might expect more harmonious race relations in the republican society of our future, but that society would still be saddled with the legacy of our past. The civic republic Tushnet envisions is not, after all, an imaginary Nowhere, but the United States of America a bit down the road. And, as he reminds us, it is a republican insight that "we find ourselves, as a matter of contingent but unavoidable fact, located in a specific community with its own history from which we cannot completely escape."218 The issue of affirmative action would therefore have to be confronted. Republicans-being less individualistic, perhaps less meritocratic, less concerned with rights per se, especially those of an abstract historical nature (such as colorblindness), and more concerned, on the other hand, with social realities, with equality of outcome as opposed to equality of opportunity-would be more likely than liberals to support the concept of affirmative action. The opposition, no longer inspired, as now, by individual or group self-interest, would come mainly from those who saw the continuing use of and preoccupa-

213 N. Machiavelli, supra note 133, bk. I, ch. 8, at 129.

214 See M. Tushnet, supra note 2 , at $248,274-75,276$.

218 Abington School Dist. v. Schempp, 374 U.S. 203 (1963) (invalidating Biblereading in public school). schools).

${ }^{216}$ Lemon v. Kurtzman, 403 U.S. 602 (1971) (invalidating state aid to parochial

${ }^{217} 268$ U.S. 510 (1925) (invalidating a state statute requiring all children to attend public school).

${ }_{218}$ M. TUSHNET, supra note 2, at 64 . 
tion with racial categories as a socially divisive breeder of stereotypes. On this issue, unlike the others previously discussed, the dialogue might indeed yield a consensus, since initial differences would be narrow and non-fundamental, having to do with matters of social prediction rather than with the tension between individual and social justice.

\section{Criminal Procedure}

There would be less crime in the New Republic than in ours: Mutual respect among citizens, a decline in avarice, greed, power-hunger, and other self-regarding passions, a greater sense of "belonging" and connectedness to the community, and a lessened sense of isolation and "anomie" would encourage obedience to the legal norms of the society. But for those who do commit crimes or are accused of having done so, republican enforcement procedures would be less protective than the procedural safeguards our judges have read into or extracted from the Constitution. The guarantees of the fourth and fifth amendments, and due process bans on particularly abusive invasions of the person are all grounded in the values of liberal individualism-liberty, privacy, property, personal dignity, physical inviolability, and exclusive ownership of one's own thoughts and words. A convincing communitarian argument for them is hard to construct. On the other hand, a relaxation of procedural requirements (those, at least, that do not contribute to the accuracy of guilt-determination) can easily be defended on communitarian or public interest grounds (assuming, of course, the necessary empirical link between procedural issues and effective law enforcement). The perceived inability of the state to protect its citizens from physical assault and to enforce its own norms of behavior is disintegrative of the very idea of community. And since most citizens, most of the time, find it easier to identify and empathize with the victims of crime than with the perpetrators (or accused perpetrators), considerations of altruism and fellow feeling are more readily enlisted on the side of vigor than restraint in enforcement.

This whirlwind survey suggests that on most issues that have given rise to constitutional controversy in recent years, neither the context of public discussion nor the ultimate legislative outcome would be much different in a republican society than in ours today. Future republican legislators would be no less likely than ours to enact the kinds of legislation that critics now call tyrannical. They would be at least as likely to prohibit or regulate pornography, homosexuality, group libel, certain forms of advertising, certain forms of campaign financing, public-figure defamation (perhaps)-all, to one degree or another, protected activities today-more likely to require or initiate broad affirma- 
tive action in the racial area, less likely to afford procedural safeguards to those accused of crime, neither more nor less likely to put prayer in the public schools or state dollars into religious schools. All of these issues would be controversial, and all proposed legislation relating to them would evoke lively opposition.

\section{B. Would civic virtue plus radical decentralization produce a politics of consensus and thereby render judicial review unnecessary?}

Tushnet might not strongly disagree with the gist of the preceding analysis. He himself appears doubtful of the claims of those republican revivalists who believe that "public values" have important substantive implications for constitutional law. ${ }^{219}$ His own argument is different: that small communities, with decentralized institutions, practicing a politics of civic virtue, will achieve consensus or unanimity enough of the time to make judicial review unnecessary. Tushnet's radical decentralization proposal raises a host of unanswered questions. It is not clear just what relationship his mini-communities, with their face-toface interaction and unanimity decision rules, would have to existing federal, state, and municipal institutions. Would they wholly displace those institutions, or at least their legislative branches? Or would they merely receive a portion of the power now exercised by state legislatures and municipal councils, and if so what portion? To the extent the existing institutions continued in business, the risk of legislative tyranny at their hands (for example, the congressional budgetary decisions that Tushnet seems to regard as exemplary) would remain no matter what might be achieved at the mini-community level, and it is unclear how unanimous decision-making at that level could possibly do away with the role of the Constitution, constitutional theory, and judicial review in relation to the other levels of government.

On the other hand, if Tushnet really means to assign his face-toface communities a large part of the legislative power of the states (and even the United States), there are obviously serious questions as to how these virtuous miniatures could effectively perform governmental functions that already overtax the capacities of much larger units. How, for example, could they possibly cope with the massive problems of drugs, crime, pollution, waste disposal, housing supply, medical care, and the like-problems that, in the view of most experts, require solutions at the regional or even the national level. The answer, from Tushnet's 
perspective, is that if all such problems were assigned to the political units that could most efficiently deal with them, there would still be plenty of subject-matter areas of a traditionally "local" nature appropriately handled by mini-communities, and that these areas-education, religion, social regulation, and others-are among the most prolific of constitutional controversies. Even this answer, however, falls far short of justifying the conclusion that the Constitution and judicial review would be unnecessary across the board.

Tushnet acknowledges, moreover, that political decentralization, without corresponding economic decentralization, could do more harm than good. ${ }^{220}$ But might not economic decentralization entail unacceptable costs in efficiency, productivity, growth, and international competitiveness? And would not the decentralization Tushnet envisions return us to the Balkan parochialism from which the framers extricated us when they replaced the Articles of Confederation with our Constitution? And would it not move us in exactly the opposite direction from that in which Europe, for its own salvation, has elected to move-dismantling the very system the Europeans now seek to emulate? Were the experiments in "community control" during the 1960 s - the fragmentation, for example, of the New York City public school system-sufficiently encouraging to wish to multiply such experiments today? It has been said that liberal individualism makes all interpersonal relations, and therefore all politics, foreign relations. Would not the multiplication and miniaturization of local decision units do the same at the inter-communal level? Would not the greater communal solidarity achieved within each local unit be paid for by a lessening of solidarity at other levels to the extent the local units related to each other as separate and quasi-independent sovereigns?

Tushnet offers no answers to questions of this kind and in a book like this is under no obligation to do so. Until his proposals are fleshed out, however, it will be difficult to evaluate them fairly or, in candor, to take them with complete seriousness.

Let us, however, put these questions of feasibility behind us and assume that the costs of Tushnet's decentralization would not be extravagant. What about the benefits? Could the small communities Tushnet contemplates really achieve a politics of unanimity or nearunanimity, and thereby resolve the problem of legislative tyranny, at least within their own (perhaps severely limited) subject-matter jurisdiction?

There is no particular reason to assume that enlightened and pub- 
lic-spirited measures, sensitive to the rights of the individual, are more likely to issue from a local than from a national legislative body; on the contrary, the lesson of our history is that small is not always beautiful. State and local governments, especially those east of the Mississippi River, have not been distinguished for civic virtue, the absence of corruption, rational dialogue, consensus decision-making, or mutual forbearance. My guess, moreover, is that a comparative analysis of the achievements of national versus state and local governments over the course of our history, including the most recent part of it, would confirm Madison's prediction that large republics would be more favorable than small ones "to the election of proper guardians of the public weal"; that taking in "a greater variety of parties and interests" would make it "less probable that a majority of the whole will have a common motive to invade the rights of other citizens" or the ability to do so; that the "influence of factious leaders may kindle a flame within their particular States, but will be unable to spread a general conflagration through the other States"; and that a rage for improper or wicked projects "will be less apt to pervade the whole body of the Union than a particular member of it," just as "such a malady is more likely to taint a particular county or district than an entire State."221

Absent the restraints of the United States Constitution-the absence Tushnet envisions-there would undoubtedly be great variation from one republican mini-community to another in their responses to the legislative issues we have canvassed. Some communities might require prayer and creationism in the schools, while prohibiting abortion, pornography, the teaching of evolution, blasphemy, profanity, sexually explicit films and seditious speech. Others might make the opposite choices on some or all of these issues. It is clear that the average level of repression would, from the standpoint of "self-styled liberals," be higher than at present, if only because many communities would opt for regulation now constitutionally forbidden to all. It is a safe assumption, moreover, that in most communities speech would be less fully protected in one way or another and that in nearly all criminal justice would be harsher.

The pattern of legislation just described would be one of ubiquitous tyranny-in the all-inclusive sense in which Tushnet seems to use the term-if it were not for the hypothesis that in all, or most, or at least many instances the actions of the community would be unanimously supported. Two questions thus arise. Is this hypothesis even remotely plausible? If so, does it negate the existence of legislative tyr-

${ }^{221}$ The Federalist, supra note 1, at No. 10 (J. Madison). 
anny and thereby make judicially enforced constitutional limitations unnecessary? The answers to both questions are no.

Consensus might be achievable if we could assume a sufficiently high degree of cultural, religious, ethnic, and economic homogeneity within each community and a corresponding commonality of values. Clearly, there are many, mainly rural, areas in the country where the homogeneous character of the initial settlers has been preserved by an absence of further influx and a relative isolation from outside influences. And, in general, the existence of marked local and regional variations in outlook can be taken for granted. But it is equally plain that in many other areas-especially urban centers marked by broad heterogeneity in their early populations, extensive comings and goings over the years, and openness to outside influence-opinions on nearly every issue will be mixed. Given the widespread and fundamental disagreement in our national society on the issues surveyed in the preceding section, it would be astonishing if that disagreement were not reproduced in some degree in almost all political units large enough to govern effectively. We may safely proceed on the assumption, therefore, that there would be initial differences in most mini-communities on most issues.

Would these initial differences be resolved through a politics of civic virtue, face-to-face interaction, and (possibly) consensus-unanimity decision rules? Sometimes yes, sometimes no. Civic virtue does not in itself guarantee consensus. Indeed, some political scientists suggest that compromise is often easier to achieve through pragmatic bargaining among competing interest groups than through a conversation among intensely opinionated ideological advocates. ${ }^{\mathbf{2 2 2}}$

Nor does face-to-face interaction necessarily lead to agreement. Social scientists have observed that such encounters frequently help to resolve initial differences when these reflect fairly tentatively held positions but may only exacerbate them when the starting positions are more firmly held; in the latter circumstances, personal interaction takes on a confrontational character and may force dissenters (not always assertive and articulate) to put up or shut up before hostile audiences, with repressive consequences. Likewise, the use of consensus or unanimity rules of decision-rules that preclude changes in the status quo when opposed by anyone who cannot be persuaded-do not always promote agreement. Here again, where the members of a community have a substantial commonality of interest and opinion on an issue, or

222 See A. Ranney \& W. Kendall, Democracy and the American Party System 508 (1956); Fitts, The Vices of Virtue: A Political Party Perspective on Civic Virtue Reforms of the Legislative Process, 136 U. PA. L. REv. 1567, 1637-38 (1988). 
across a range of issues, consensus or unanimity rules may enable them to work out superficial differences or to find elusive common ground. But where initial differences of interest or opinion are real and resistant, the use of such decision rules may become a prescription either for paralysis (the tyranny of the minority) or for the social repression of dissent in pursuit of a spurious unanimity. ${ }^{223}$

To these social scientific findings, I might add one or two homespun impressions. Law school faculties have many of the characteristics of Tushnet's republican communities. We are small; we know one another's "foibles and contributions"; we are given to endless dialogue, some of it rational; we pride ourselves on our civic virtue (which we often call "institution-mindedness"). Yet mutual forbearance is not an unfailing characteristic of law faculty deliberations nor unanimity its invariable outcome. Consider, too, the Supreme Court of the United States-small group, rational dialogue, close and long-standing collegiality and friendship, yet no greater consensus on the major socially divisive issues than the society as a whole. The Court achieves unanimity in only a third of its cases (mainly those of less visibility and importance) and the maximum discordance-five-to-four decisions-in nearly one-fifth. ${ }^{224}$

As further evidence against the unanimity hypothesis, I would cite the experience of late eighteenth-century Americans, nearly all of whom called themselves republicans and paid lip service to civic virtue, but who often sharply disagreed on nearly everything else, including whether or not to ratify the proposed new Constitution.

Assuming, however, for argument's sake, that unanimity would be achieved in most communities on most issues, would that negate legislative tyranny and do away with the need for judicial review? Not at all. For one thing, the standard of achievement-most communities on most issues-is too low; coercion without consent would still be present in some, perhaps many, instances and tyranny would persist. More important, it would eventually emerge even in those communities, and on

${ }^{223}$ See J. Mansbridge, Beyond Adversary Democracy 31-34, 149-62, 252 63, 270-74 (1980).

224 During the 1981 through 1987 terms, the Supreme Court decided 954 cases with full opinion, an average of 159 per term. The number of 5-4 decision was 192 (an average of 32 per year), approximately $20 \%$ of the total. The total number of unanimous decisions (including those with one or more concurring opinions) was 322 about (54 per term), roughly $34 \%$. These figures are derived from the statistical tables entitled "5-4 decisions" and "Unanimity" in the Harvard Law Review's annual analyses of The Supreme Court Term for the period in question. 96 HARV. L. REV. at 306-07 (1982); 97 HaRv. L. Rev. at 297-98 (1983); 98 HaRv. L. Rev. at 309-10 (1984); 99 HaRv. L. Rev. at 324-25 (1985); 100 HaRv. L. REv. at 306-07 (1986), and 101 HARv. L. REv. at 364-65 (1987). 
those issues, where unanimity was initially achieved. Granted, immediately after the unanimous adoption of a legislative measure, it might be fair to say that all had consented and none therefore was coerced. In time, however, the weight of community opinion might change yet the legislation remain. New residents might move in who did not know about, or at any rate never approved, the legislation; their consent would be no less fictitious than that of new residents under our present majority-rule system. Other dissenters, below the age of participation at the time of enactment, or perhaps not even born, might now have come of age. To them also, the law might well seem tyrannical. Still others might simply have changed their minds. The existence of a unanimity decision rule would make it nearly impossible for a new value consensus to form or to secure a change in the law-for example, repeal of an abortion statute, repeal or enactment of an affirmative action program, exclusion or inclusion of prayer in school. Thus, regulations that might once have reflected the unanimous sentiment of the community might now be at odds with the view of the majority yet remain obdurately on the books until that majority approached unanimity, or a sufficiently coercive semblance thereof. Professor Tribe, moreover, has taught us how difficult it is for a new consensus to take shape so long as the old statute remains in effect, a prime justification, in his view, for the exercise of judicial review. ${ }^{225}$ In Tushnet's republican vision, judicial review would not be around to perform that clearing-the-slate function.

\section{G. Would civic virtue at the legislative level eliminate the} difference in perspective that is the raison d'etre of judicial review, making it both redundant and illegitimate?

The most plausible argument for Tushnet's conclusion that a republican society would have no need for constitutional limitations or institutional constraints, including judicial review, is that it would be redundant, illegitimate, or both for a court to second-guess the decisions of a civically virtuous legislature. Legislative virtue would make judicial vigilance both unnecessary and inappropriate.

Putting aside any doubts one might have as to the prospects for banishing self-interest from the political process, there is certainly much force in the argument that the need and justification for judicial oversight of legislation is inversely related to the difference in perspective between the two institutions. Nor is the point confined to judges: If both Houses of Congress and the President viewed all issues through

${ }^{225}$ See Tribe, Structural Due Process, 10 HaRv. C.R.-C.L. L. REv.269, 314-19 (1975). 
the same prism, the benefits of requiring their joint concurrence would be considerably reduced. The point is clearest where the legislative decision as to community values and the public interest reflects the unanimous judgment of the republican citizenry and its representatives; there the judicial outcome would be a foregone conclusion and the exercise entirely superfluous. The cloudier and more controversial the issue, and the weaker the popular and legislative consensus supporting the statute, the greater becomes the possibility of judicial disagreement. Even so, the very fact that the legislative decision is animated solely by concern for the long-term public good, and not at all by individual or factional self-interest, and that the well-being of the opponents of the law has been taken fully into account, is an argument against the legitimacy of judicial intervention that is not available in our current culture, where courts can be seen as having a perspective both wider and longer than that of legislatures.

There are, however, answers to this argument. One is facetious: that a society committed to endless dialogue, in which every decision is subject to instant reconsideration, might well be willing to let a court hear a litigant's argument that the statute under which he is being prosecuted (especially if it were an old one) is no longer consistent with the public interest or the current values of the community. Today's judicial decision may be as accurate an expression of community values as yesterday's, or last decade's, legislative decision. This argument presupposes, of course, a constitutional theory that instructs judges to apply contemporary community values in interpreting the Constitution rather than the two-hundred-year old values of the framers.

A more serious answer is that Tushnet's notion of the uselessness of judicial review or other institutional constraints assumes that civic virtue, once achieved, would be self-perpetuating. That assumption ignores the corrosive effects of time and change on the stablest of human institutions, a danger classic thinkers of the republican tradition never forgot. They were keenly aware that civic virtue was a fleeting thing, here today gone tomorrow. They knew that it would always be under assault from the baser (if not basic) aspects of human nature: its selfishness, avarice, and hunger for power. They knew that institutional arrangements were necessary to hold these tendencies in check; and for that reason the idea of checks and balances embodied in the theory of mixed government was scarcely less fundamental to them than civic virtue itself. The Constitution-judicially enforceable, as the framers decided-was the mast to which the republic, Ulysses-like, tied itself for defense against the ever-dangerous siren song of self-interest, corruption, and power abuse-the assumption, of course, being that the 
judges, life-tenured and professionally disciplined, would be less vulnerable to that song than the legislators.

In sum, Tushnet's argument that a republican society would have no use for judicial review would be regarded by a republican traditionalist as shockingly unhistorical, indifferent alike to the actual experience of past republics and to the teachings of past republican theorists and, as such, out of keeping with the historicist emphasis of the tradition itself.

\section{ConCLusion}

If ultimately we cannot rely on judges to save our society from tyranny, and could not in our right (or left) minds have ever expected to do so, what must we rely on instead? Nearly forty years ago Judge Learned Hand gave a wise answer:

that a society so riven that the spirit of moderation is gone, no court can save; that a society where the spirit flourishes, no court need save; that in a society which evades its responsibility by thrusting upon courts the nurture of that spirit, that spirit in the end will perish. What is the spirit of moderation? It is the temper which does not press a partisan advantage to its bitter end, which can understand and will respect the other side, which feels a unity between all citizens - real and not the factitious product of propaganda which recognizes their common fate and their common aspirations - in a word, which has faith in the sacredness of the individual. ${ }^{228}$

Mark Tushnet, I suspect, would applaud this statement and claim it for the republican tradition. Most liberals would likewise endorse it. If that means the two world views are not worlds apart, so be it. 
. 